\title{
Remote sensing of glaciers in the Canadian Cordillera, western Canada
}

Wheate, Roger D ; Berthier, Etienne ; Bolch, Tobias ; Menounos, Brian P ; Shea, Joseph M ; Clague, John J ; Schiefer, Erik

DOI: https://doi.org/10.1007/978-3-540-79818-7_14

Posted at the Zurich Open Repository and Archive, University of Zurich ZORA URL: https://doi.org/10.5167/uzh-102086

Book Section

Published Version

Originally published at:

Wheate, Roger D; Berthier, Etienne; Bolch, Tobias; Menounos, Brian P; Shea, Joseph M; Clague, John J; Schiefer, Erik (2014). Remote sensing of glaciers in the Canadian Cordillera, western Canada. In: Kargel, Jeffrey S; Leonard, Gregory J; Bishop, Michael P; Kääb, Andreas; Raup, Bruce H. Global Land Ice Measurements from Space. Berlin: Springer, 333-352.

DOI: https://doi.org/10.1007/978-3-540-79818-7_14 


\title{
Remote sensing of glaciers in the Canadian Cordillera, western Canada
}

\author{
Roger D. Wheate, Etienne Berthier, Tobias Bolch, Brian P. Menounos, Joseph M. Shea, \\ John J. Clague, and Erik Schiefer
}

\begin{abstract}
We review the use of spaceborne imagery and digital elevation models (DEMs) to evaluate glacier thinning and retreat in the Canadian Cordillera, an area that includes the provinces of British Columbia (BC), Alberta, and Yukon Territory. Glaciers in Alberta and British Columbia lost $11.1 \pm 3.8 \%$ of their area over the period 1985-2005, which represents an approximate annual shrinkage rate of $0.55 \%$. For the period 1985-1999 the average thinning rate of sampled glaciers was $0.78 \pm 0.19 \mathrm{~m} / \mathrm{yr}$ water equivalent (w.e.), which equates to an annual volume loss of $22.48 \pm 5.53 \mathrm{~km}^{3}$. Mean annual ice loss in the Yukon between 1977 and 2007 was $5.5 \pm 1.7 \mathrm{~km}^{3} / \mathrm{yr}$, while the average mass balance for Yukon glaciers over this period was $-0.45 \pm 0.09 \mathrm{~m} / \mathrm{yr}$. We also summarize changes in glacier extents and surface elevation from 1965 to 2005 , and include examples of surging glaciers in the Yukon and glacier hazards in British Columbia.
\end{abstract}

\subsection{INTRODUCTION}

The size and remoteness of the Cordillera of western Canada has resulted in limited resources for monitoring the region's glaciers. A federal mapping program at 1:50,000 scale commenced in the 1950s, with later mapping by provincial agencies at a scale of 1:20,000 in the 1980s. In both cases, technicians employed photogrammetric methods to extract glacier outlines from black-and-white aerial photos. Canada's contribution to the International Hydrological Decade (1965-1974) included repeat mapping of selected glaciers along an east-west transect across the Cordillera in conjunction with long-term mass balance studies (Østrem 1973, Ommanney 2002a). Peyto Glacier in Banff National Park has the longest and most reliable mass balance record in western Canada (Østrem 2006).

Most research prior to 1990 mapped changes in glacier extent in western Canada using aerial photos, due both to reduced accessibility to satellite imagery and lower rates of glacier recession concealing noticeable differences (e.g., Luckman et al. 1987). Gratton et al. (1990) and Sidjak and Wheate (1999) used Landsat TM imagery to characterize Illecillewaet Glacier in Glacier National Park, BC. DeBeer and Sharp (2007) evaluated recent changes in glaciers in southern $\mathrm{BC}$ and Alberta $\left(50-51^{\circ} \mathrm{N}\right)$ based on comparison of glacier extents from aerial photography of the mid-1950s and Landsat imagery acquired in 2001-2002. Schiefer et al. (2007) quantified the total change in glacier area and volume in $\mathrm{BC}$ by differencing photogrammetric digital elevation models dating to the mid1980s and elevation data from the 2000 Shuttle Radar Topography Mission (SRTM). VanLooy and Forster (2008) focused on changes in five ice- 
fields in the southern Coast Mountains from 1927 to the first decade of this century.

Glaciers in the Yukon, mostly in Kluane National Park, have attracted considerable attention from glaciologists. A summer field program at Trapridge Glacier has operated continuously from 1969 to 2010 (Clarke 2005). Studies on Trapridge Glacier have yielded numerous scientific advances that have improved our understanding of ice dynamics and how ice flow is affected by subglacial hydrology. Field studies are continuing in this region with a research program on a small glacier in the Donjek Range (De Paoli and Flowers 2009). Satellite-based studies of Yukon glaciers are rare, although exceptions include research by Kargel et al. (2005), Barrand and Sharp (2010), and Berthier et al. (2010). Clarke and Holdsworth (2002b) also presented Landsat images of Yukon glaciers and Landsat-derived ice velocities. Melt of glaciers in the St. Elias Mountains is currently one of the major contributors to global sea level rise (Arendt et al. 2002, Berthier et al. 2010).

Recent satellite-based studies, which examined regional changes in glacier volume for western Canada, have also calculated their potential contributions to sea level rise. These include Schiefer et al. (2007) for BC glaciers, Barrand and Sharp (2010) for Yukon glaciers, and Berthier et al. (2010) for Alaskan glaciers, which incorporated bordering areas of $\mathrm{BC}$ and the Yukon. Further regional studies have analyzed the role of topography on glacier morphometry and change. Schiefer et al. (2008) explored the relationships between glacier length, area, elevation, and aspect for BC glaciers, while DeBeer and Sharp (2009) focused on topographic influences on changes in small glaciers for a portion of southern BC. The Landsat-based inventory for western Canada by Bolch et al. (2010) included analysis of glacier area change relative to glacier size, elevation, and topographic aspect.

\subsection{REGIONAL CONTEXT}

\subsubsection{Topographic setting}

The Canadian Cordillera was formed by collisions between the North American Plate and a series of island arcs associated with the Farallon/Kula Plates. The present tectonic boundary, between the North American and Pacific lithospheric plates, is marked by the Queen Charlotte strike-slip fault system that lies to the west of the major northwest to southeast-trending mountain ranges across British Columbia. To the south, the Juan de Fuca Plate separates the North American and Pacific Plates and is subducting beneath the western margin of North America. The Western Cordillera is bounded by two major mountain ranges with the Coast Mountains on the west and the Rocky Mountains on the east. Between the Coast and Rocky Mountains are many other ranges separated by plateaus and broad valleys including the Columbia Mountains, containing the Cariboo, Monashee, Selkirk, and Purcell Mountains in the south, and the Cassiar, Hazelton, Omineca, and Skeena Mountains in the north. The Rocky Mountain Trench separates the Rocky Mountains on the east from the Columbia and Cassiar Mountains on the west (Fig. 14.1). In the far northwest, the St. Elias Mountains extend into British Columbia from Alaska and the Yukon. These mountains contain the largest icefields and glaciers in western Canada and are among the most rugged on Earth (Clarke and Holdsworth 2002b). The glacier threshold in the Cordillera rises in elevation to the south and east. Mean glacier elevation is lower than $1,250 \mathrm{~m}$ asl in the northern Coast Mountains, but exceeds 2,750 m asl in the southern Rocky Mountains (Schiefer et al. 2007).

\subsubsection{Climate}

The Canadian Cordillera is located in the zone of midlatitude westerlies, and thus mean annual precipitation decreases eastward across the region. Annual snowfall is highest in the northern Coast and St. Elias Mountains. Here, precipitation is greatest during the winter months due to the passage of North Pacific cyclones across the coast. Interactions between frontal systems and topography in the southern Coast and Rocky Mountains produce heavy winter precipitation west of the Rockies, while spring and summer precipitation play an important role east of the Continental Divide, with more restricted water resources (Shea et al. 2004, Barry 2008, Marshall et al. 2011). Local to regional-scale topography, and the larger scale controls mentioned above, affect glacier mass balance in the Canadian Cordillera.

\subsubsection{Glacier distribution and characteristics}

The distribution of glaciers in the Coast, Rocky, and St. Elias Mountains has been extracted from 


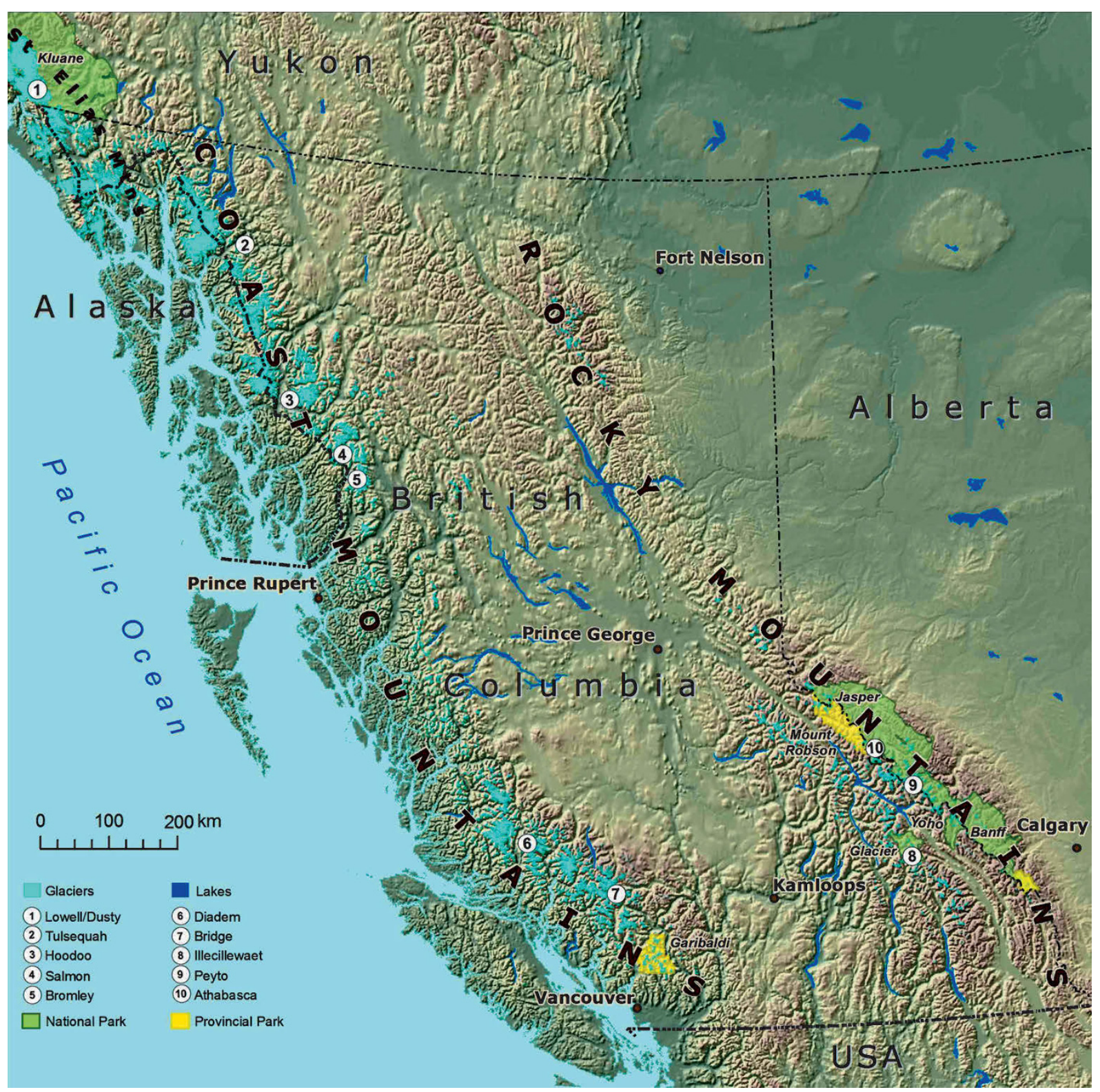

Figure 14.1. The Western Cordillera of Canada and its glaciers; numbered glaciers are cited in the text.

Landsat Multispectral Scanner (MSS) images by Clarke and Holdsworth (2002a, b) and Ommanney (2002b). There are approximately 15,000 glaciers in western Canada. Glaciers covered $2.6 \%$ of BC $\left(26,700 \mathrm{~km}^{2}\right)$ in 2005 (Bolch et al., 2010). Schiefer et al. (2008) provide a complete inventory of glaciers in $\mathrm{BC}$, building on earlier glacier inventories and mass balance and glaciation level studies by Østrem (1973) and Ommanney (1980). About $2.5 \%\left(\sim 12,500 \mathrm{~km}^{2}\right)$ of Yukon Territory is ice covered. Alberta glaciers cover a total area less than $800 \mathrm{~km}^{2}$, confined to the Rocky Mountains in the westernmost part of the province. Most Yukon glaciers are located in the St. Elias Mountains in the southwest corner of the territory, close to its borders with Alaska and BC.

Glaciers in the Canadian Cordillera range from large icefields and associated outlet glaciers to valley and cirque glaciers. The largest icefields and much of the total glacier area occur in the St. Elias Mountains and in the southern and northern Coast Mountains. The central Coast Mountains have less extensive ice cover due to their lower elevations. The importance of elevation controls 
on glaciation levels is also apparent in the Rocky Mountains, where in contrast to the Coast Mountains, the higher ranges in the south support more extensive ice cover than lower ranges in the north. On the west coast of $\mathrm{BC}$, there are isolated alpine glaciers in the Insular Mountains of Vancouver Island.

Clarke and Holdsworth (2002b) provide an overview of the thermal and physical characteristics of glaciers in the St. Elias Mountains, where more than two thirds of all surging glaciers in western North America are located. In 1980, a 103 m long ice core was recovered from a high elevation site (5,340 $\mathrm{m}$ asl) near Mt. Logan (5,959 m asl). Moore et al. (2002) extended the Mt. Logan ice core record to the year 2000 based on shallow cores and snow pits. They found a positive accelerating trend in snow accumulation after the middle of the 19th century.

\subsection{SPECIAL TOPICS AND CASE STUDIES}

In this section, we describe the use of satellite imagery for detecting and monitoring hazards associated with glacierized terrain and for assessing changes in a glaciovolcanic environment. The four case studies in Section 14.3.1 describe hazards associated with recent glacier retreat caused by climate warming. In Section 14.3.2 we highlight further examples of satellite and field-based image evidence of sustained glacier retreat.

\subsubsection{Glacier hazards}

\subsubsection{Outburst flood from Queen Bess Lake, 1997}

Queen Bess Lake $\left(51.3^{\circ} \mathrm{N}, 124.5^{\circ} \mathrm{W}\right)$, located in the southern Coast Mountains of BC, rapidly drained on August 12, 1997, when its Little Ice Age moraine dam was overtopped and incised by a huge displacement wave (Fig. 14.2). The wave was triggered by a large icefall from Diadem Glacier, which clings to the steep rock slope above Queen Bess Lake. The icefall occurred during a warm rainy period when large amounts of water were discharging from the base of Diadem Glacier. More than 6 million $\mathrm{m}^{3}$ of water escaped from the lake, producing a flood that devastated the valley of the west fork of the Nostetuko River valley below the dam. The overtopping waters also incised the outflow channel

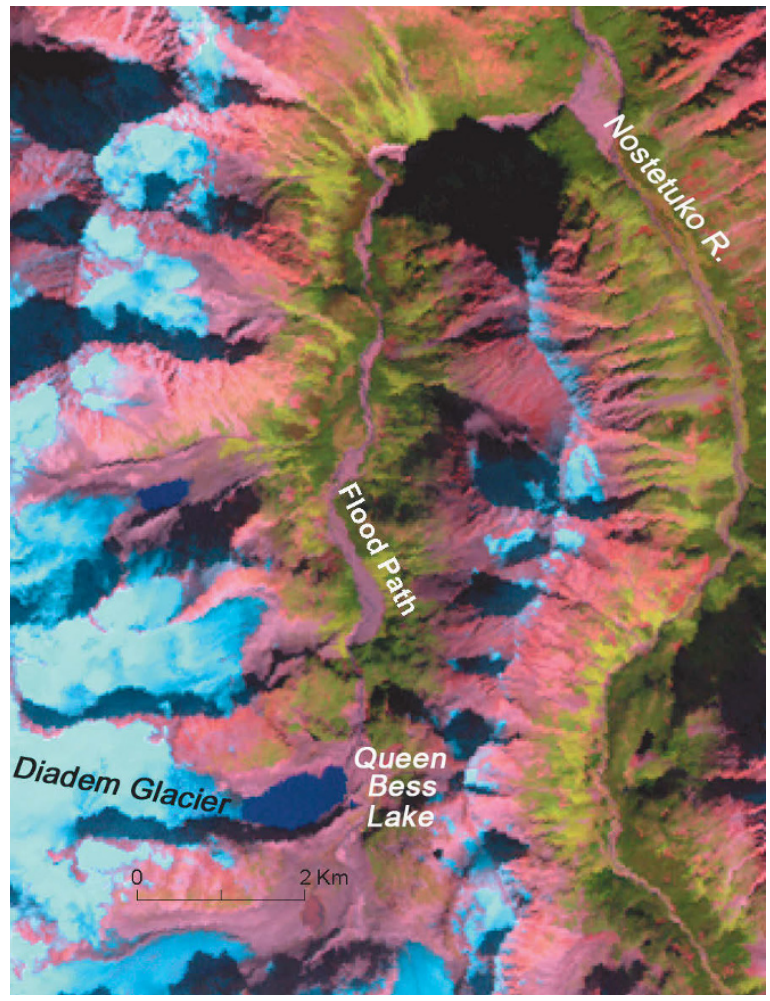

Figure 14.2. Track of outburst flood from Queen Bess Lake: Landsat $7 \mathrm{ETM}+543$ color composite, October 3, 2001.

across the moraine. The flood had two phases, one related to wave overtopping and a second to breach formation. The floodwaters scoured the full width of the valley, removing mature forest and leaving a sheet deposit of gravelly sediment in their wake. Sediments were deposited both upstream and downstream of channel constrictions and on a large fan at the mouth of the west fork of Nostetuko Valley $9 \mathrm{~km}$ from Queen Bess Lake. The flood continued another $100 \mathrm{~km}$ downstream to the mouth of Bute Inlet.

The event is significant because it was preconditioned by climate change - climate warming in the 20th century caused Diadem Glacier to retreat to a position where its toe became unstable and then failed, triggering the wave that overtopped and breached the moraine (Kershaw et al. 2005).

\subsubsection{Outburst floods from Summit Lake}

Glacier-dammed Summit Lake $\left(56.2^{\circ} \mathrm{N}, 130.0^{\circ} \mathrm{W}\right)$ is located in the northern Coast Mountains near the Alaska-BC boundary (Fig. 14.3). Salmon Glacier impounds the lake approximately $11 \mathrm{~km}$ from its 


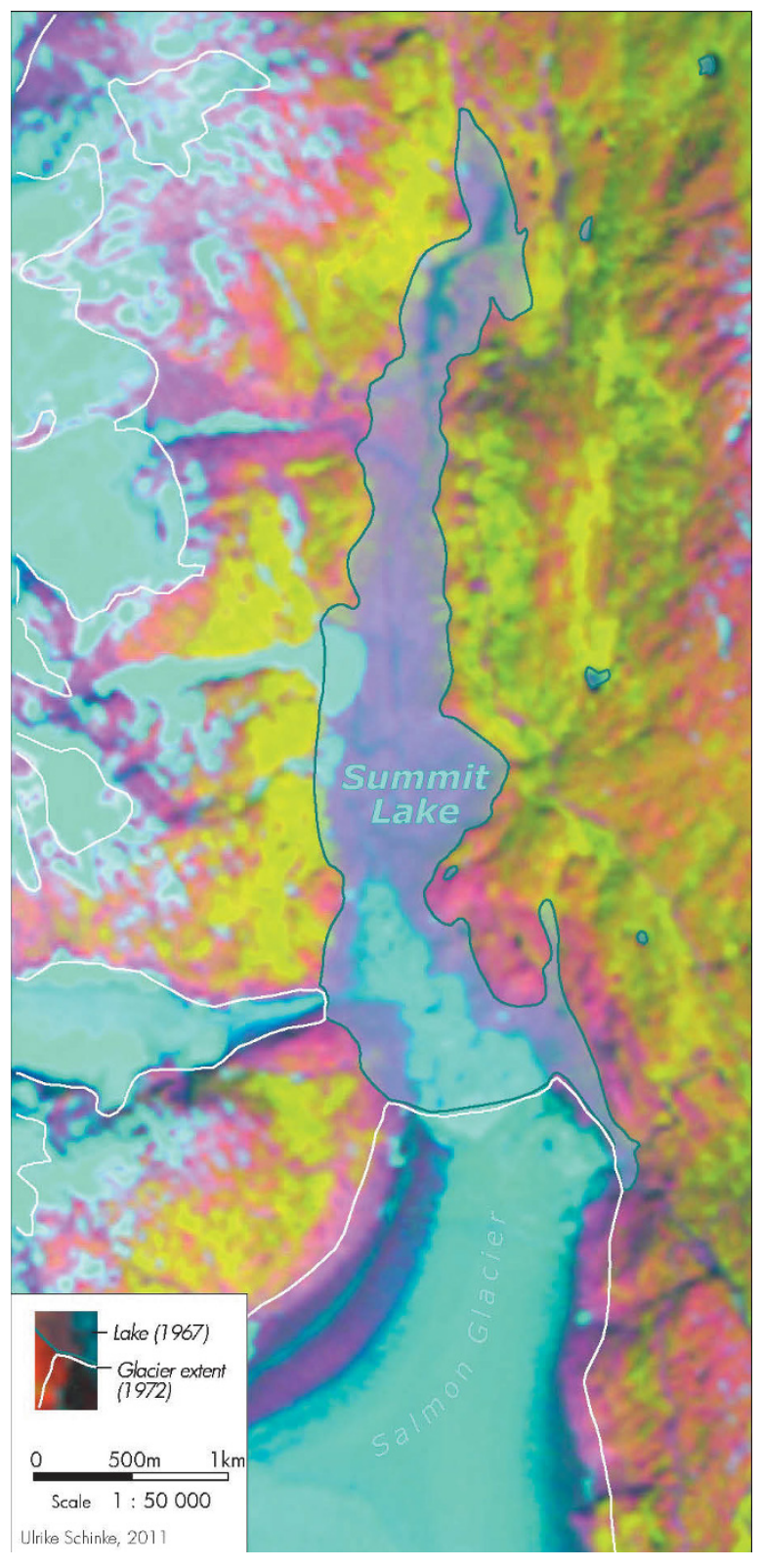

Figure 14.3. Landsat 5 TM 543 color composite, August 4, 2010, showing previous extent (1972) of Salmon Glacier. Also shown is the extent of glacierdammed Summit Lake on federal maps and aerial photos taken in 1967.

terminus. Meltwater issuing from Salmon Glacier flows via Salmon River $23 \mathrm{~km}$ south, past the town of Hyder, Alaska, to tidewater at the head of Portland Canal. When full, Summit Lake is $0.45-1.25$ $\mathrm{km}$ wide, more than $200 \mathrm{~m}$ deep at the ice dam, and has a storage capacity of $0.25 \mathrm{~km}^{3}$. Until 1961, the lake contained few icebergs and was stable, overflowing to the north into the Bowser River valley. In
December 1961, after a lengthy period of thinning and retreat of Salmon Glacier, Summit Lake suddenly drained through a subglacial tunnel in the weakened ice dam. This flood and two others in 1965 and 1967 caused major damage to the road system in the Salmon River valley south of the lake. Since 1965, with a few exceptions, Summit Lake drains to the south each year. These outburst floods (jökulhlaups) in recent years have been smaller and have occurred earlier in the year than floods prior to 1961. Rapid water level fluctuations associated with the annual emptying and refilling of Summit Lake generates large numbers of icebergs, derived from the Salmon Glacier dam; today these icebergs choke the surface of the lake. The present cycle of jökulhlaups is likely to continue either until the glacier readvances or until it retreats to the point that it no longer forms an effective seal (Mathews and Clague 1993).

\subsubsection{Tulsequah Glacier and its lakes}

Tulsequah Glacier $\left(58.8^{\circ} \mathrm{N}, 133.8^{\circ} \mathrm{W}\right)$, a large valley glacier in northwest BC, dams Tulsequah Lake (Fig. 14.4). Jökulhlaups have regularly occurred from this lake since the early 20th century. The floods commenced after decades of downwasting and retreat of the glacier (Geertsema and Clague 2005). Tulsequah Lake formed in the early 1900s when a tributary glacier separated from Tulsequah Glacier, creating an ice-free embayment between the two. The lake's area and volume rapidly increased in the first half of the 20th century, but later, with continued glacier retreat, it decreased in size. The first jökulhlaups from Tulsequah Lake were the largest. Peak and total discharges decreased as the lake became smaller. Today, Tulsequah Lake is small, and it will disappear completely if Tulsequah Glacier retreats any further. A second lake (Lake No Lake), however, has formed and grown in size as Tulsequah Lake has diminished (Fig. 14.4). Lake No Lake developed from a subglacial water body in a tributary valley, $7 \mathrm{~km}$ upglacier from Tulsequah Lake. Like Tulsequah Lake, Lake No Lake's area and volume initially increased until the 1970s after which jökulhlaups became common. Lake No Lake appears to be following the same evolutionary path as Tulsequah Lake - its volume is now decreasing due to downwasting of Tulsequah Glacier and jökulhlaup frequency and volume are declining. As Tulsequah Glacier continues to shrink in response to climatic 


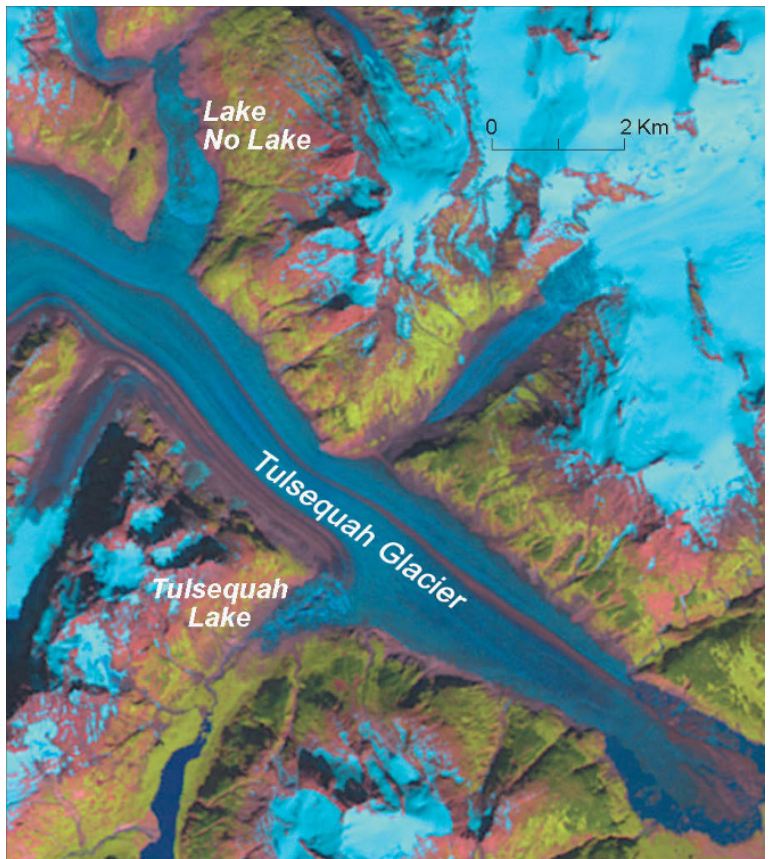

Figure 14.4. Tulsequah Glacier, Landsat 5 TM 543 color composite, July 29, 2006. Both Lake No Lake and Tulsequah Lake are covered by ice. warming, additional glacier-dammed lakes may form, renewing the cycle of outburst flood activity.

\subsubsection{Capricorn Creek landslide, 2010}

One of the largest historic landslides in western Canada occurred at Mount Meager in southwest BC on August 6, 2010 (Fig. 14.5). The instability at the head of Capricorn Creek $\left(50.6^{\circ} \mathrm{N}, 123.5^{\circ} \mathrm{W}\right)$ is at least in part related to debuttressing of slopes formerly ice covered. Capricorn Glacier covered the lower part of the slope during the Little Ice Age, but has since downwasted and retreated. Approximately 48 million $\mathrm{m}^{3}$ of highly fractured Pleistocene volcanic rocks detached from the southwest flank of the mountain. The detached rock mass, which contained much water, rapidly fragmented as it entered the headwaters of Capricorn Creek, a steep tributary of Meager Creek. The landslide transformed into a debris flow that traveled $8 \mathrm{~km}$ down Capricorn Creek at an average speed of $60 \mathrm{~m} / \mathrm{s}$ to Meager Creek. The debris flow dramatically superelevated at bends along this part of its path-locally by more than $250 \mathrm{~m}$. It then entered the valley of Meager

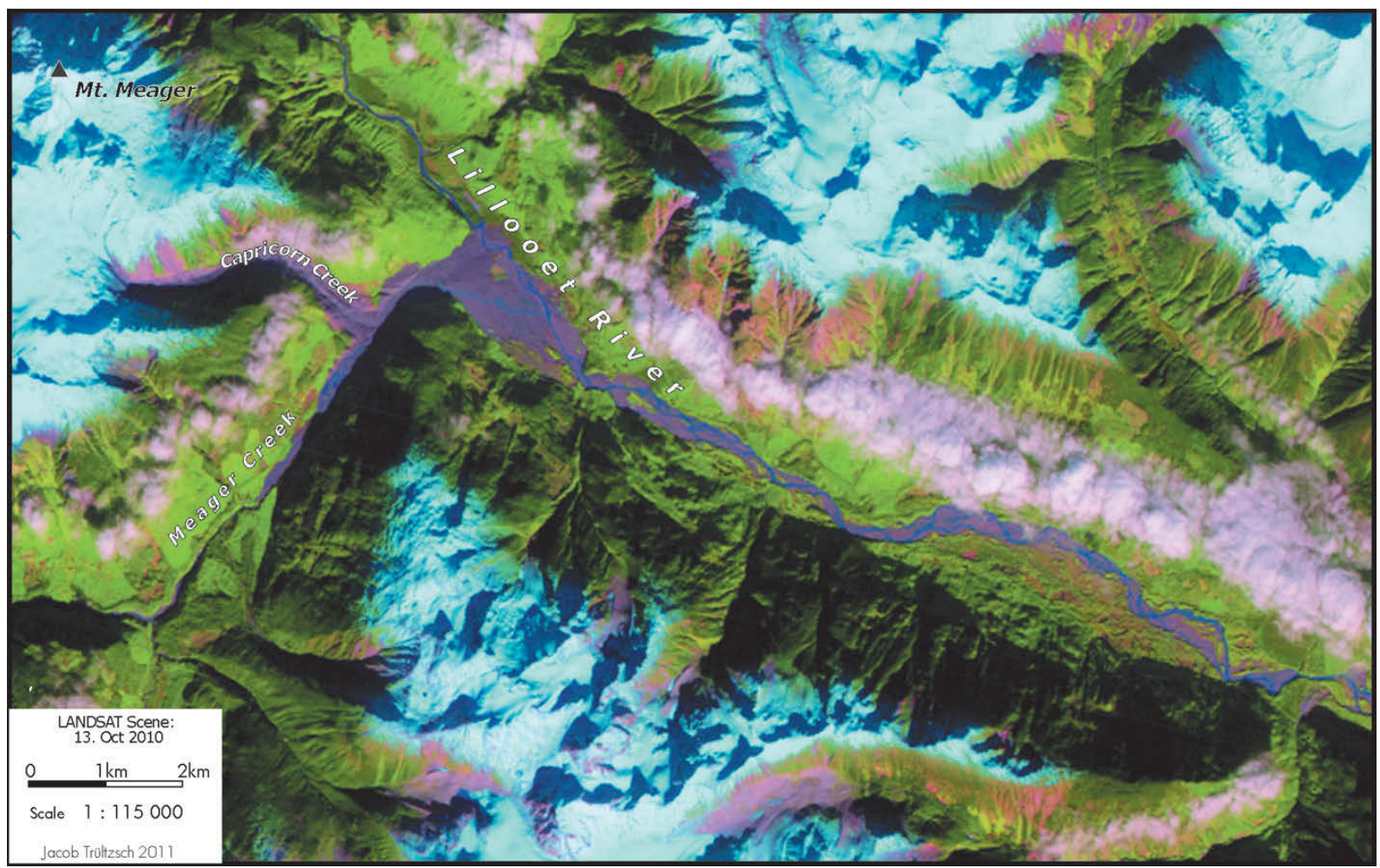

Figure 14.5. Extent of landslide (dark purple) from Meager Mountain in the valleys of Capricorn Creek, Meager Creek, and Lillooet River; Landsat 5 TM 543 color composite, October 13, 2010. 
Creek and climbed $270 \mathrm{~m}$ up the northwest-facing wall of that valley. There it bifurcated into two lobes: one lobe ran almost $4 \mathrm{~km}$ to the southwest up Meager Creek valley, and the other traveled northeast down Meager Creek to the Lillooet River, nearly $13 \mathrm{~km}$ from the source. Landslide debris blocked Meager Creek at the mouth of Capricorn Creek for about $19 \mathrm{~h}$, impounding the river and creating a lake that reached up to $1.5 \mathrm{~km}$ long. Debris in Lillooet River valley stemmed the flow of Lillooet River for about $2 \mathrm{~h}$. Concern over a possible outburst flood from the lake in the valley of Meager Creek led to the evacuation of 1,500 people in the town of Pemberton. The debris dam in the valley of Meager Creek was overtopped and incised, but the resulting flood wave did not overtop levees along Lillooet River and the residents of Pemberton were allowed to return to their homes the following day. The landslide was recorded by seismometers in BC and Washington State. It is the third large landslide in the Capricorn Creek watershed since 1998 and the fifth such event in the Meager Creek watershed since 1930, indicative of the increased rate of warming.

\subsubsection{Glacier changes}

\subsubsection{Bridge Glacier, southern Coast Mountains, British Columbia}

Bridge Glacier $\left(50.8^{\circ} \mathrm{N} 123.5^{\circ} \mathrm{W}\right)$ is located in the Chilcotin Range, southwest BC. It is a large valley glacier fed from several accumulation basins with a total area of $88 \mathrm{~km}^{2}$. Ground-based studies indicate annual velocities of over $100 \mathrm{~m} / \mathrm{yr}$ in the center of the glacier. The glacier presently terminates in a proglacial lake. Calving of ice into the lake is likely driven by flotation of part of the terminus and warm-water advection at the calving face. Late-summer images obtained from Landsat MSS, TM, ETM+, and ASTER show extensive calving, downwasting, and retreat of the terminus from 1976 to 2010 (Fig. 14.6). Between 1985 and 2006, the surface of the glacier near the 2010 terminus lowered by approximately $140 \mathrm{~m}$, or $6.6 \mathrm{~m} / \mathrm{yr}$. Downwasting is also evident around the bedrock knob in the middle left of Fig. 14.6, and the northern glacier tributary became separate from the trunk of Bridge Glacier shortly after 1999. Also notable is reestablishment of vegetation below the Little Ice Age trimline and upvalley encroachment of vegetation in successive images from 1976 to 2010. The trimline is the product of multiple ice front oscillations between the 15th and early 20th centuries (Allen and Smith 2007). The portion of the lake that is generally free of icebergs is only a few meters deep, but provides access to the site by floatplane (Fig. 14.6e). Stahl et al. (2008) suggested that future retreat of Bridge Glacier will lead to nearly a $40 \%$ reduction in August flow to Bridge River by the year 2050 .

\subsubsection{Dusty and Lowell Glaciers, Yukon}

Two neighboring glaciers, Dusty $\left(60.4^{\circ} \mathrm{N}, 138.4^{\circ} \mathrm{W}\right)$ and Lowell $\left(60.3^{\circ} \mathrm{N}, 138.4^{\circ} \mathrm{W}\right)$, located in adjacent valleys on the southeastern flank of the St. Elias Mountains, Yukon Territory, behaved differently between 1977 and 2007. Lowell Glacier terminates in a large proglacial lake, whereas the proglacial lake in front of Dusty Glacier is small. Dusty Glacier is the only large glacier in the Yukon that increased in thickness over this 30-year period. In contrast, Lowell Glacier thinned considerably. To illustrate the changes in these two glaciers during the past decade, we examined one Landsat 7 ETM+ (1999) and two ASTER (2003, 2006) images. The Landsat image was orthorectified during the GINA project (http://www.gina.alaska.edu/data/landsatdata). The ASTER images were orthorectified using ground control points (GCPs) collected from the Landsat scene on the ice-free terrain to ensure the best co-registration of the three images. The elevations of these GCPs were extracted from the 1977 Yukon Geomatics DEM derived from map contours. Perspective 3D views were then produced to better visualize glacier area and volume changes (Fig. 14.7); a sequence of three images was also created to highlight the changes (Figs. 14.8 and 14.9). The animation clearly shows an advance and thickening of the lower part of Dusty Glacier between 1999 and 2003. The advance was a result of a surge, which ended sometime between 2003 and 2006. Strong deformation of the medial moraine is evident where two tributaries merge. The animation also clearly illustrates how the looped moraines formed. The southward shift of the medial moraine indicates that this surge resulted from inflow of ice from the northernmost tributary of Dusty Glacier. The thickened terminus of Dusty Glacier began to thin by 2006. Lowell Glacier lost ice in its terminus lake by large-scale calving. The area of ice loss at the calving front between 1999 and 2003 is $7 \mathrm{~km}^{2}$; an additional $1.3 \mathrm{~km}^{2}$ was lost between 2003 and 2006. 
(a)

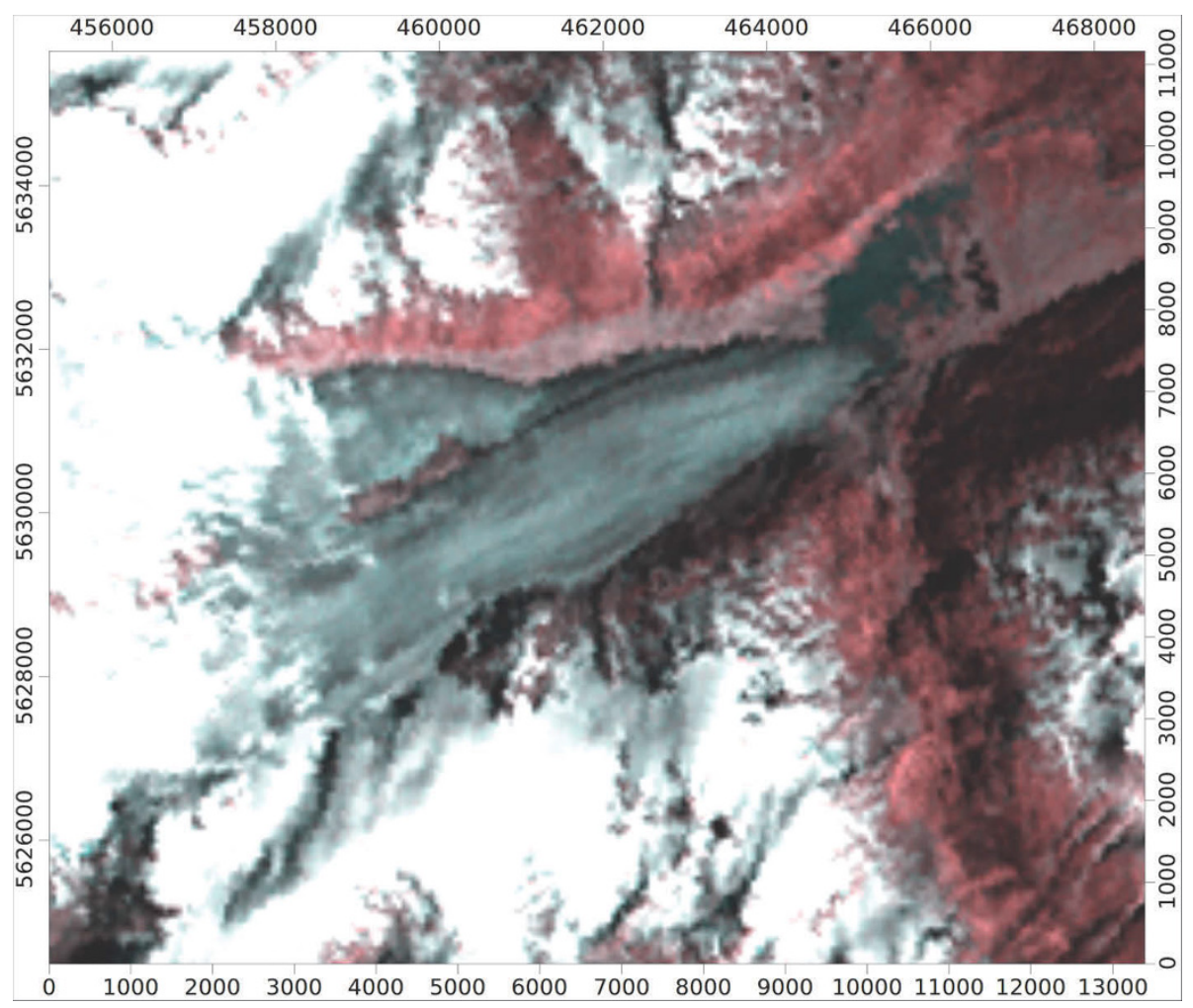

(b)

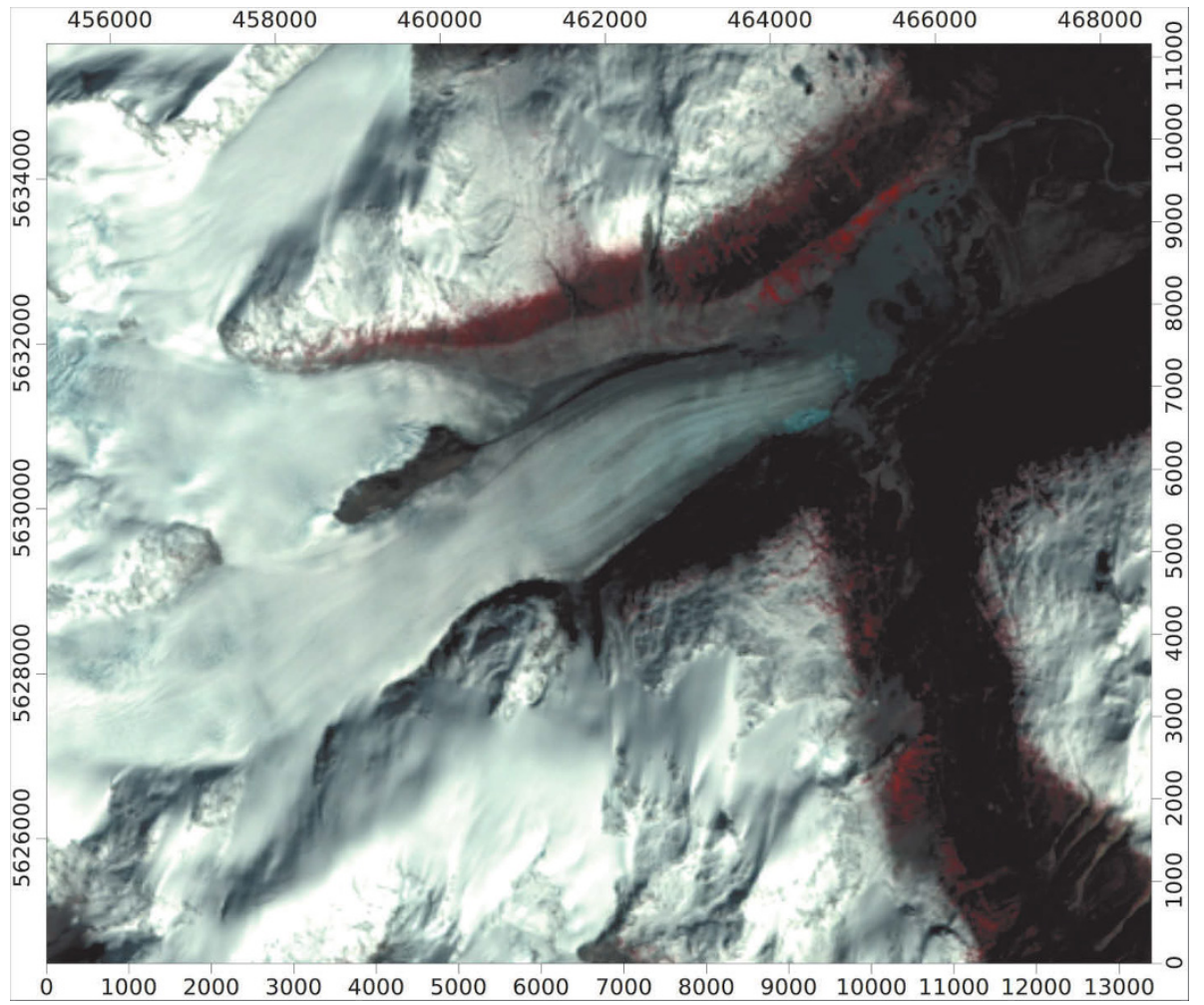

Figure 14.6. Bridge Glacier, false-color composites (near IR, red, green): (a) Landsat 1 MSS September 20, 1976, (b) Landsat 5 TM September 25, 1986. Northings and eastings (left and top axes, respectively) are given in UTM $10 \mathrm{~N}$, WGS 84 coordinates, and bottom and right axes are given in meters. 
(c)

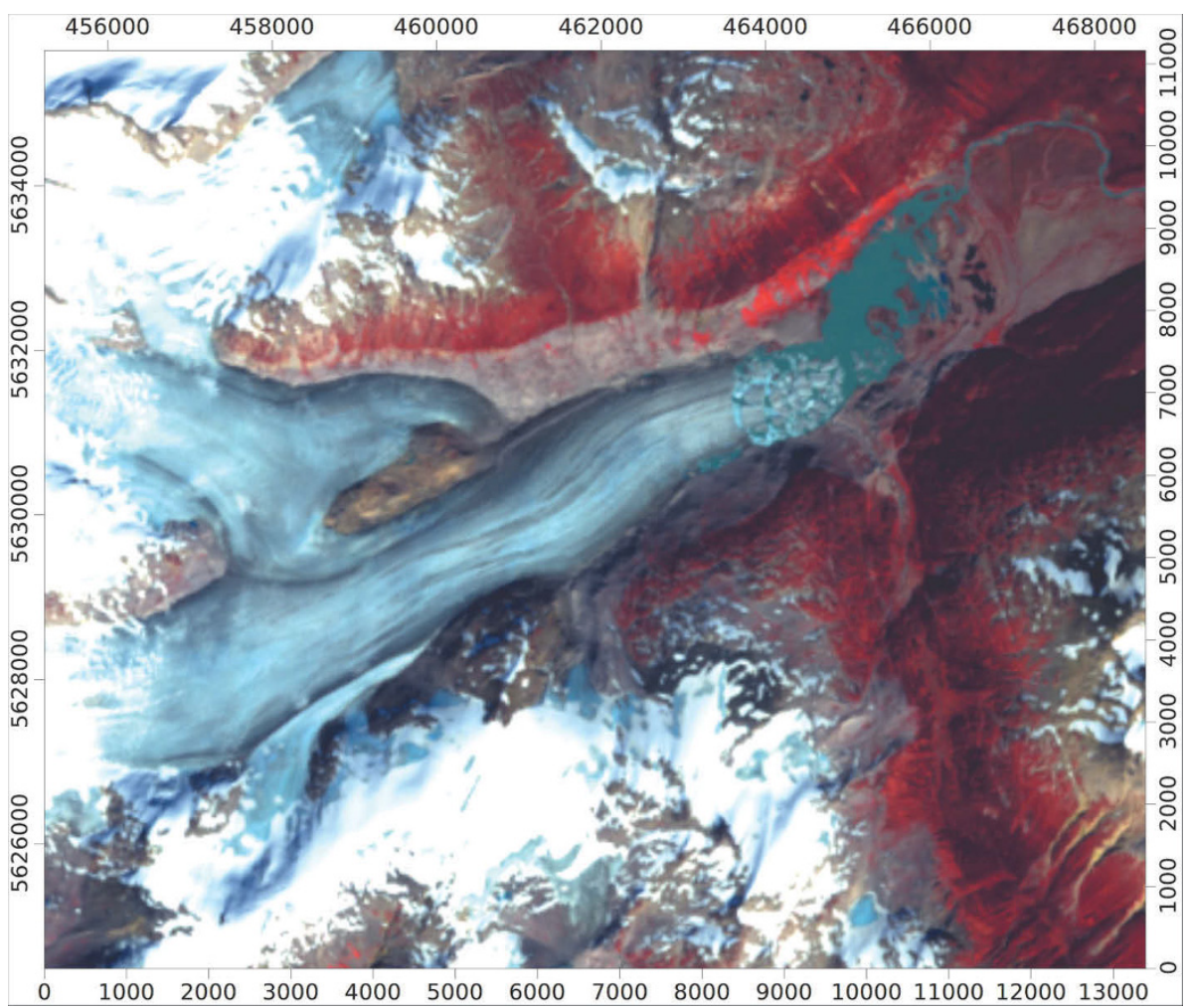

(d)

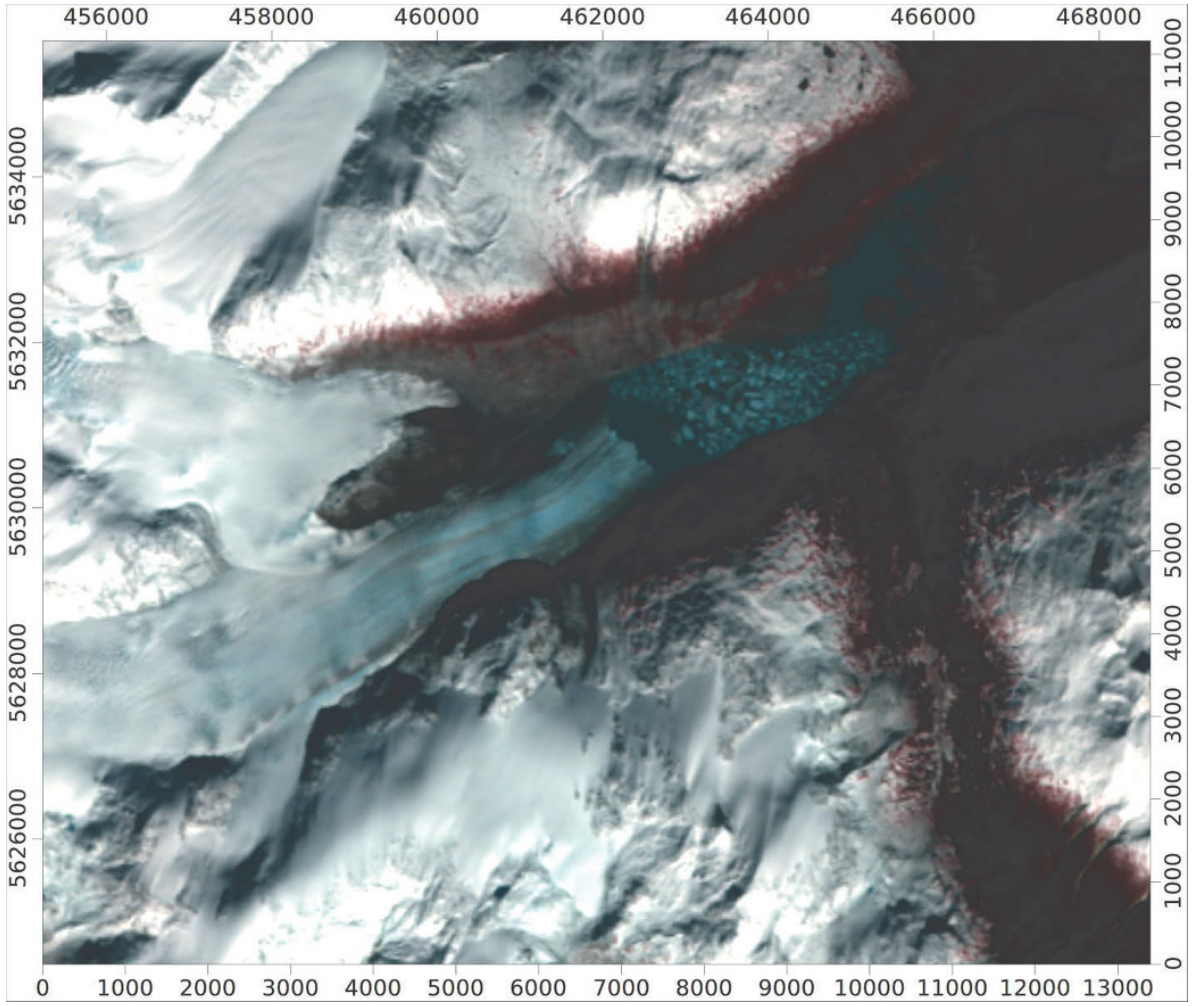

Figure 14.6. Bridge Glacier, false-color composites (near IR, red, green): (c) Landsat 7 ETM+ September 23, 2000, (d) ASTER August 4, 2010. Northings and eastings (left and top axes, respectively) are given in UTM 10N, WGS84 coordinates, and bottom and right axes are given in meters. 


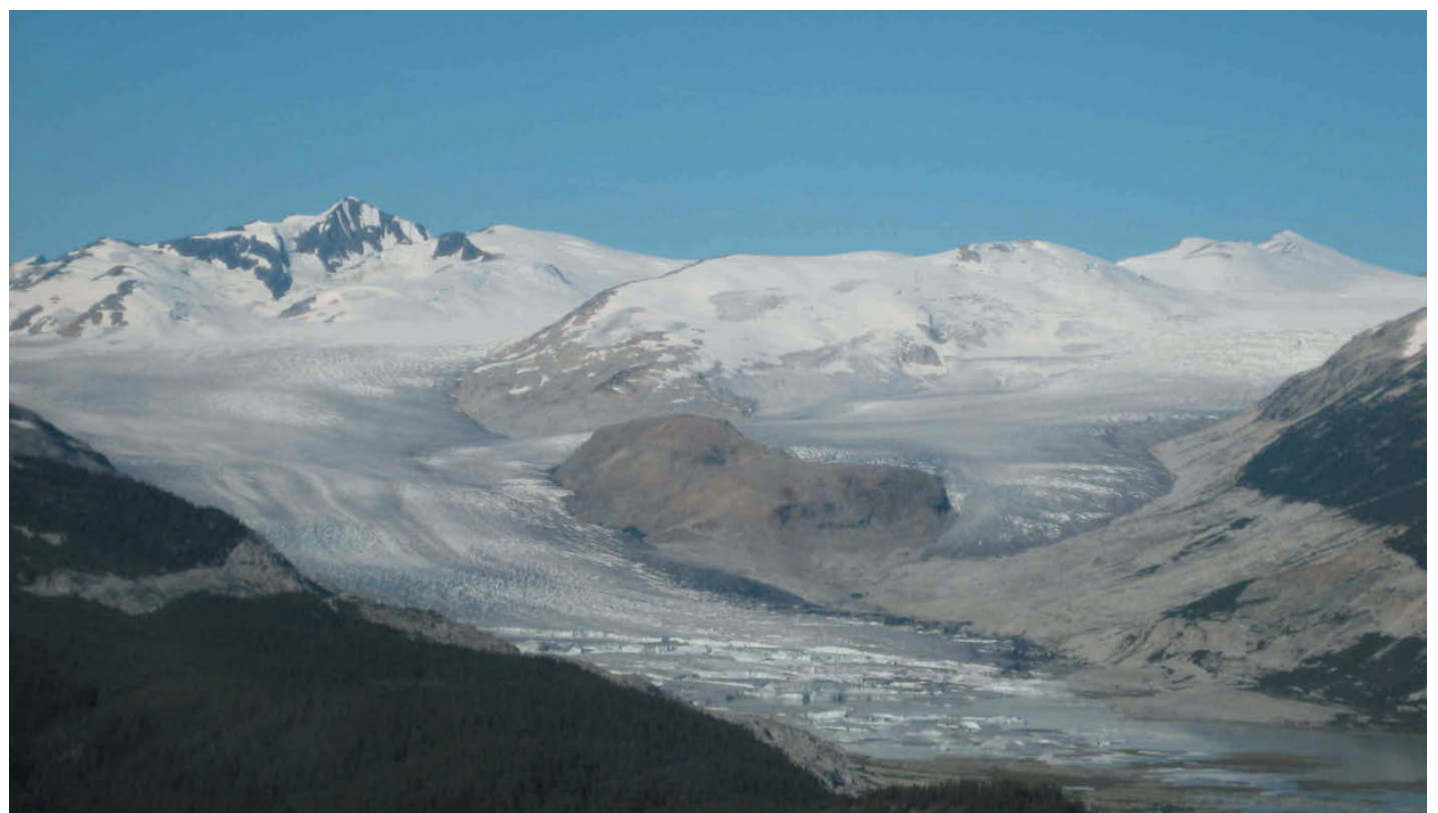

Figure 14.6. (e) View of Bridge Glacier and proglacial lake from the east, September 2006. Bridge Peak (2,925 m) is on the left (photo by Joseph Shea).

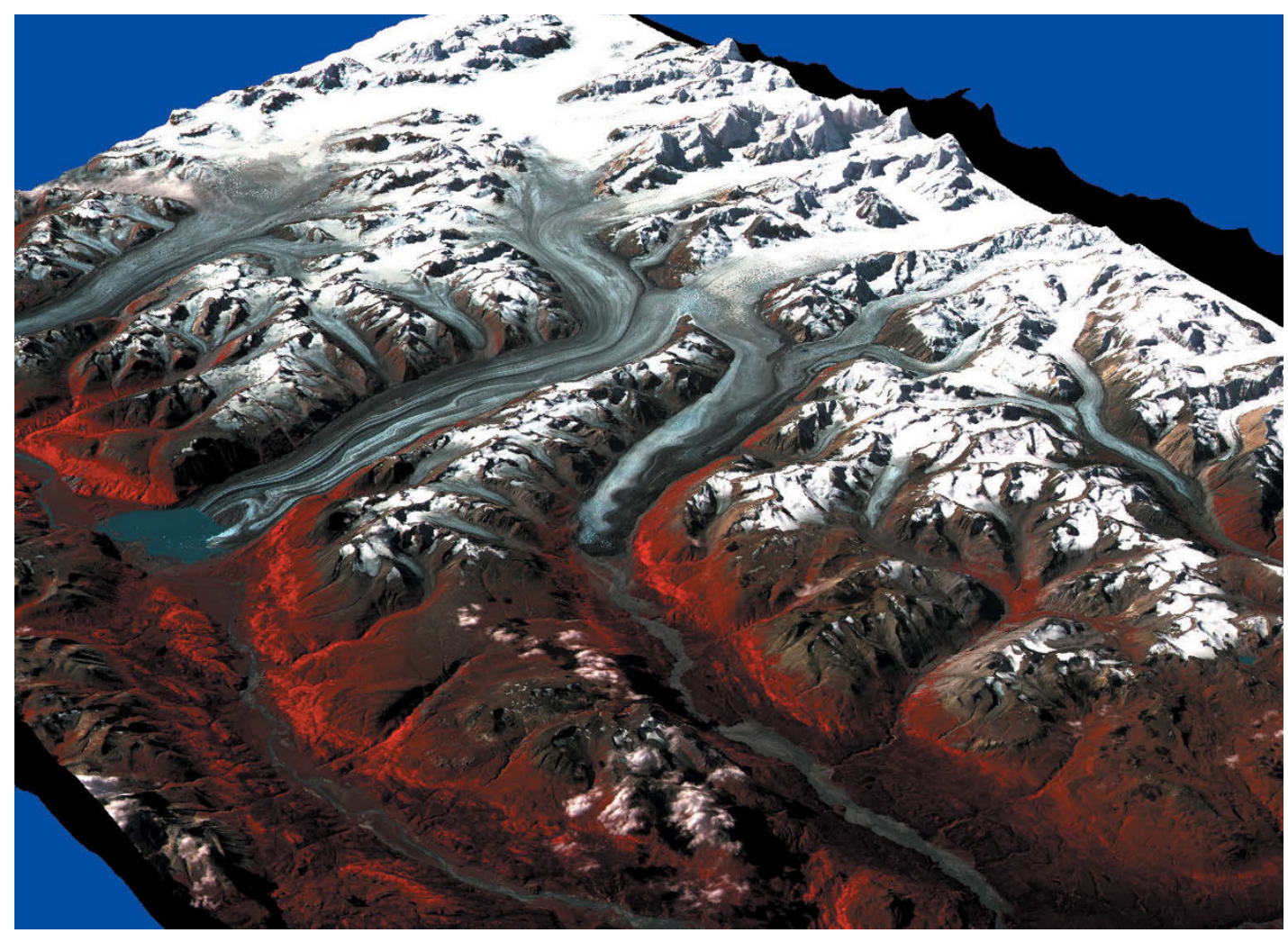

Figure 14.7. Lowell and Dusty Glaciers (center left, with large blue proglacial lake; and center of image, respectively), ASTER 3D view, 321 false-color composite, September 11, 2003. 

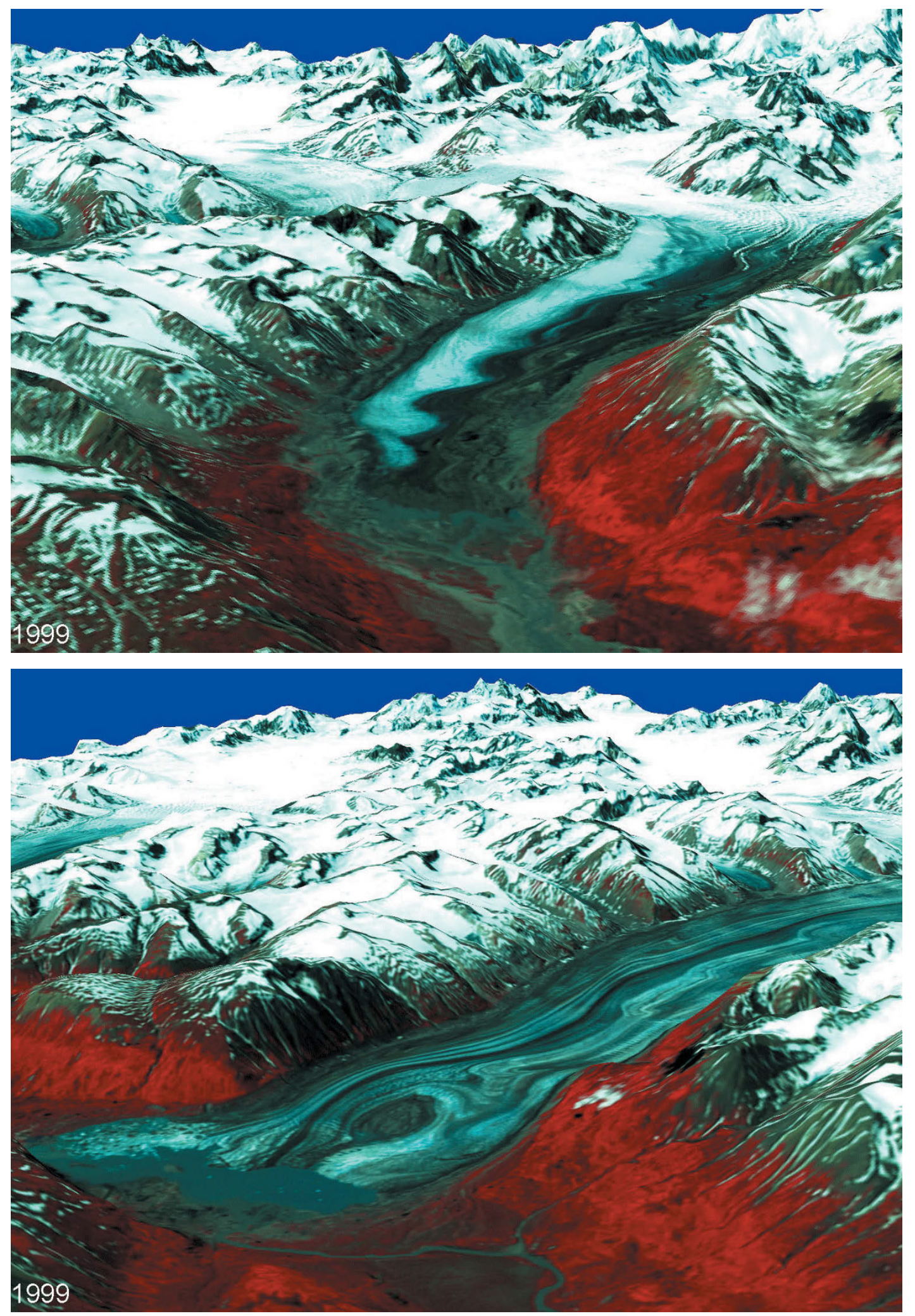

Figure 14.8 and 14.9. 1999 frames of animated GIF showing the contrasting evolution of Dusty and Lowell Glaciers (top and bottom images, respectively) between 1999 (July 14) and 2006 (July 17), false-color composites (near IR, red, green bands) (see Online Supplements 14.1 and 14.2, which are animated GIF sequences). 


\subsection{REGIONAL GLACIER INVENTORIES AND SYNTHESIS}

\subsubsection{British Columbia and Alberta}

Bolch et al. (2010) compared glacier extents from provincial mapping in the 1980 s with more recent satellite image data to generate a new glacier inventory and to examine the rate of retreat. They used 43 Landsat TM scenes with a median date of 2005 provided by the BC Ministry of Forestry (Fig. 14.10). A semiautomated approach was used to delineate glaciers, based on the red/mid-infrared band ratio (TM3/TM5). Some manual editing was needed to recognize debris-covered ice, which is commonly spectrally similar to adjacent bedrock and debris, as well as turbid meltwater lakes at glacier margins. The resulting glacier extents for western Canada (2005) were contributed to the GLIMS database in summer 2009. Fig. 14.11 shows an example of glacier change in the northern Coast Mountains, based on the 1982 BC provincial mapping, a 2005 Landsat scene, earlier federal mapping from 1965, and a more recent (2010) Landsat image.

The total area of ice loss between 1985 and 2005 was approximately $3,336 \mathrm{~km}^{2}$ or $11 \%$ of the total glacierized area in 1985 - an average annual rate of loss of about $0.55 \%$, calculated as total loss divided by the number of years (Table 14.1). The greatest

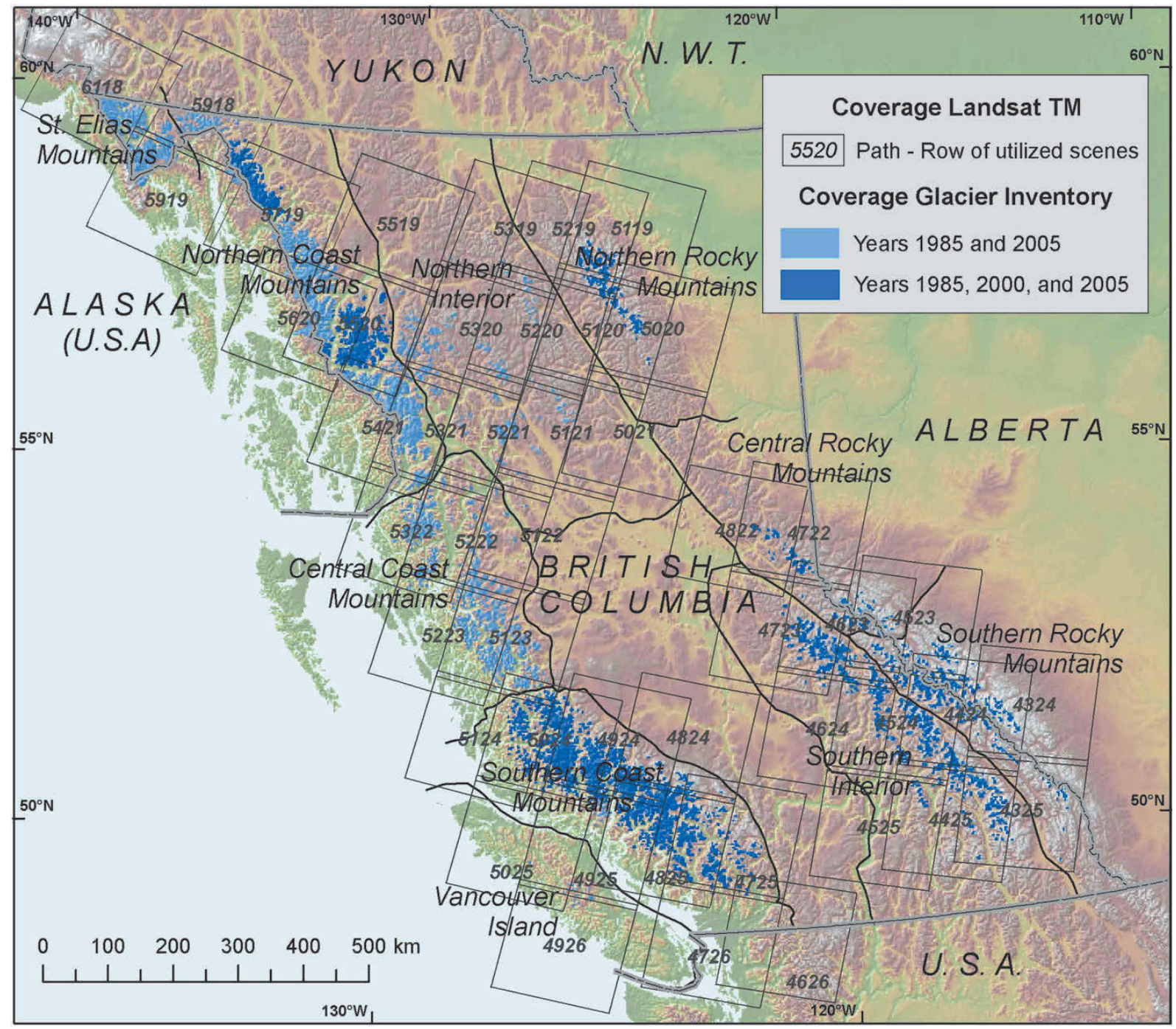

Figure 14.10. Landsat TM scenes used for the 2005 glacier inventory in western Canada (reproduced with permission from Bolch et al. 2010; Elsevier). 


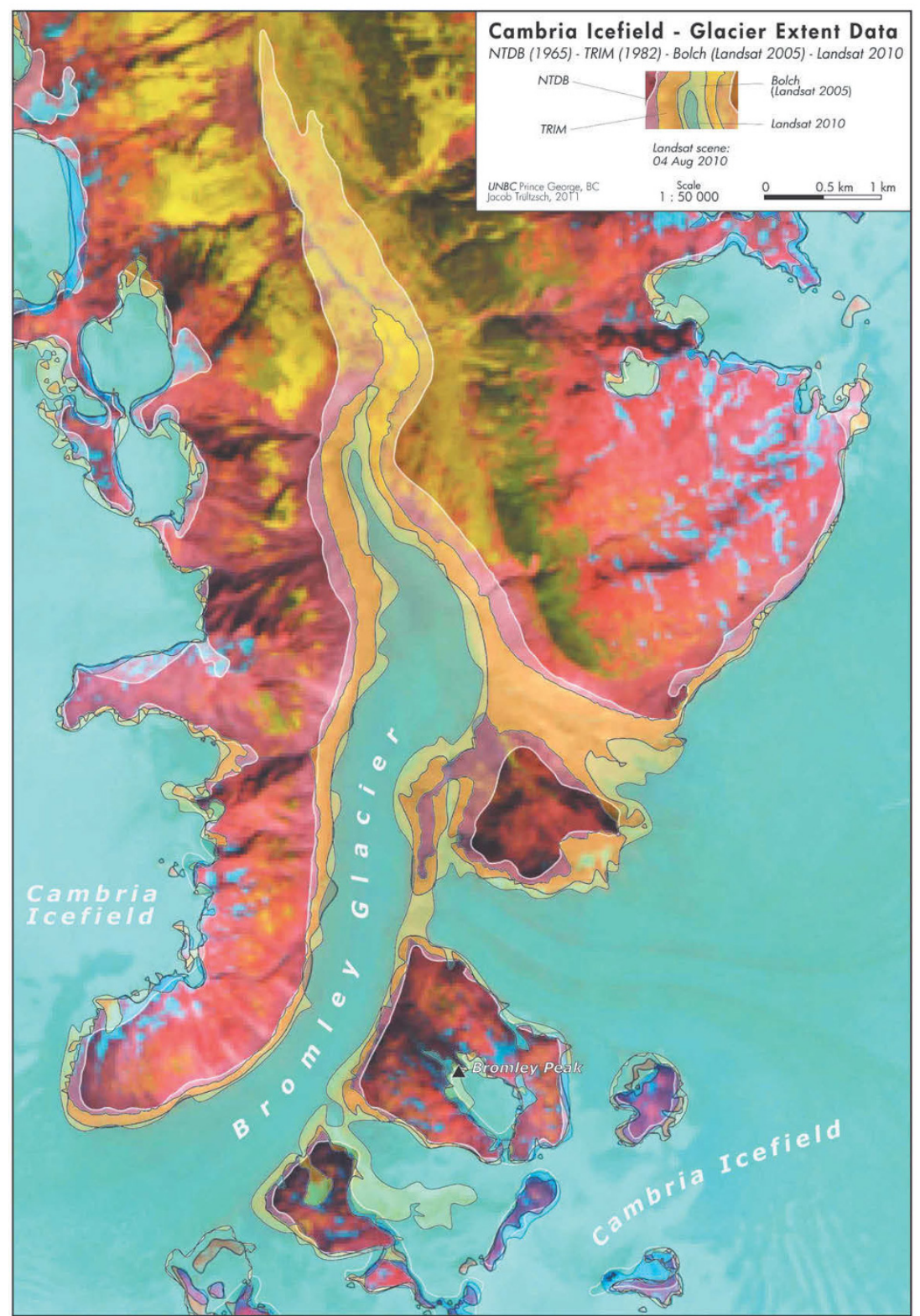

Figure 14.11. Extents of Bromley Glacier, Cambria Icefield (56 $\left.\mathrm{N} 129.75^{\circ} \mathrm{W}\right)$ in 1955, 1982, 2005, and 2010, overlain on a Landsat 5 TM 543 color composite from August 5, 2010. Figure can also be viewed as Online Supplement 14.3 .

area lost was from the larger glaciers and icefields in the St. Elias and Coast Mountains, but the relative percentage of ice loss was greater for smaller glaciers in the Rocky Mountains and the BC interior. The largest percentage losses were experienced by small glaciers on Vancouver Island and by glaciers in the Alberta Rocky Mountains, the most continental of the glaciers in the region.

We also estimated the total volume loss of glacier ice in British Columbia for the period 1985-1999 by differencing the $\mathrm{BC}$ provincial DEM and
SRTM terrain model. The bias-corrected thinning rate (Schiefer et al. 2007) for this period is $0.78 \pm 0.19 \mathrm{~m} / \mathrm{yr}$, yielding an annual volume loss of $22.48 \pm 5.53 \mathrm{~km}^{3}$ (w.e.). This volume corresponds to $0.67 \pm 0.12 \mathrm{~mm}$ of sea level rise over the 14-year period. In contrast to glacier area losses, thinning rates do not appear to differ significantly between mountain ranges, with the possible exception of the small glaciers of Vancouver Island, although the uncertainties in the thinning estimates are largely due to reflection brightness in glacier 
Table 14.1. Glacier area change 1985-2005, with estimated uncertainties (modified from Bolch et al. 2010).

\begin{tabular}{|l|c|c|c|c|c|c|}
\hline Region & $\begin{array}{c}\text { Area } \\
1985 \\
\left(\mathrm{~km}^{2}\right)\end{array}$ & $\begin{array}{c}\text { Area } \\
2005 \\
\left(\mathrm{~km}^{2}\right)\end{array}$ & $\begin{array}{c}\text { Mean glacier } \\
\text { size 1985 } \\
\left(\mathrm{km}^{2}\right)\end{array}$ & $\begin{array}{c}\text { Area change } \\
1985-2005 \\
\left(\mathrm{~km}^{2}\right)\end{array}$ & $\begin{array}{c}\text { Area change } \\
(\%)\end{array}$ & $\begin{array}{c}\text { Annual rate } \\
1985-2005 \\
(\%)\end{array}$ \\
\hline St. Elias & 3,616 & 3,330 & 7.0 & $-285 \pm 123$ & $-7.9 \pm 3.4$ & $-0.44 \pm 0.19$ \\
\hline Northern Coast & 10,863 & 10,029 & 3.5 & $-834 \pm 367$ & $-7.7 \pm 3.4$ & $-0.35 \pm 0.15$ \\
\hline Central Coast & 2,078 & 1,625 & 0.9 & $-453 \pm 102$ & $-21.8 \pm 4.9$ & $-1.21 \pm 0.27$ \\
\hline Southern Coast & 7,912 & 7,097 & 2.1 & $-814 \pm 300$ & $-10.3 \pm 3.8$ & $-0.61 \pm 0.22$ \\
\hline Vancouver Island & 18 & 14.5 & 0.3 & $-3.4 \pm 1.2$ & $-20.0 \pm 7.3$ & $-1.11 \pm 0.40$ \\
\hline Northern Interior & 697 & 530 & 1.0 & $-167 \pm 32$ & $-24.0 \pm 4.6$ & $-1.20 \pm 0.23$ \\
\hline Southern Interior & 2,253 & 1,910 & 1.2 & $-342 \pm 99$ & $-15.2 \pm 4.4$ & $-0.72 \pm 0.21$ \\
\hline Northern Rockies & 497 & 418 & 1.1 & $-79 \pm 23$ & $-15.9 \pm 4.6$ & $-0.79 \pm 0.23$ \\
\hline Central Rockies & 509 & 420 & 1.4 & $-89 \pm 21$ & $-17.5 \pm 4.1$ & $-0.88 \pm 0.21$ \\
\hline Southern Rockies & 1,587 & 1,352 & 1.5 & $-235 \pm 65$ & $-14.8 \pm 4.1$ & $-0.67 \pm 0.19$ \\
\hline Totals & 30,063 & 26,728 & 2.1 & $-3,336 \pm 1142$ & $-11.1 \pm 3.8$ & $-0.55 \pm 0.19$ \\
\hline BC & 28,233 & 25,218 & 2.1 & $-3,056 \pm 990$ & $-10.8 \pm 3.5$ & $-0.54 \pm 0.17$ \\
\hline Alberta & 1,054 & 786 & 1.1 & $-268 \pm 43$ & $-25.4 \pm 4.1$ & $-1.27 \pm 0.20$ \\
\hline
\end{tabular}

accumulation areas. Comparison of the provincial 1985 elevations with earlier federal DEM elevations $(1965 / 1970)$ for selected areas suggests that the rate of ice loss for the period 1985-1999 is approximately double that for the previous two decades (Schiefer et al., 2007).

We have assembled four complete DEM datasets for $\mathrm{BC}$, although all have associated errors and uncertainties (Fig. 14.12a-d). The earliest two datasets are produced from federal (1950s-1980s) and provincial $(\sim 1985)$ aerial photos. The federal DEM is derived from digitized map contours and can suffer from a "terracing effect" (sudden drops in elevation) on low-gradient surfaces near glacier termini and in upper accumulation areas. The provincial photos were acquired mainly for forested terrain and commonly are saturated in accumulation areas, with low contrast and fewer elevation points collected. The two more recent datasets are produced from spaceborne imagery: the SRTM dataset has a lower spatial resolution $(90 \mathrm{~m})$ and a bias with elevation of $-12 \mathrm{~m} / \mathrm{km}$ (Schiefer et al. 2007), whereas the ASTER GDEM dataset comprises scenes acquired between 2000 and 2008.
Although each dataset includes images acquired over years to as much as decades, some assessments of elevation change and glacier thinning can be made between sets of DEMs. Fig. 14.13 shows glacier thinning from 1967 to 2005 for an area in the northern Coast Mountains that includes Salmon, Berendon, and Frank Mackie Glaciers, near the Alaska-BC boundary. Thinning near the terminus of Salmon Glacier, which can be accessible by road in summer from the towns of Stewart, BC and Hyder, Alaska, exceeds $200 \mathrm{~m}$ or $5 \mathrm{~m} / \mathrm{yr}$. As the later date (2004) is an approximation based on the ASTER GDEM, exact rates of thinning should be treated with caution. Online Supplement 14.4 includes a sequence of four hillshaded DEMS of this area for 1965, 1982, 1999, and ca. 2004. In the next chapter (Chapter 15) Kargel et al. highlight a different subsection of the hillshaded DEM for the Hoodoo Mountain area of British Columbia.

\subsubsection{Yukon}

Our digital inventory of Yukon glaciers (Fig. 14.14) is based on the 1:50,000-scale Canadian National 


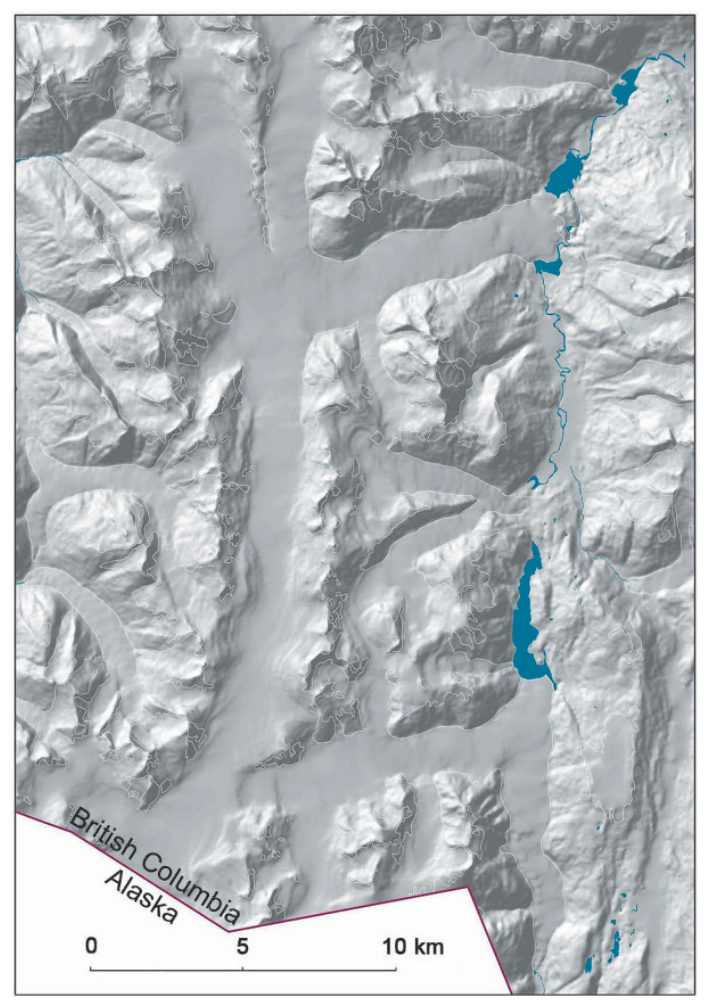

(a)

(b)
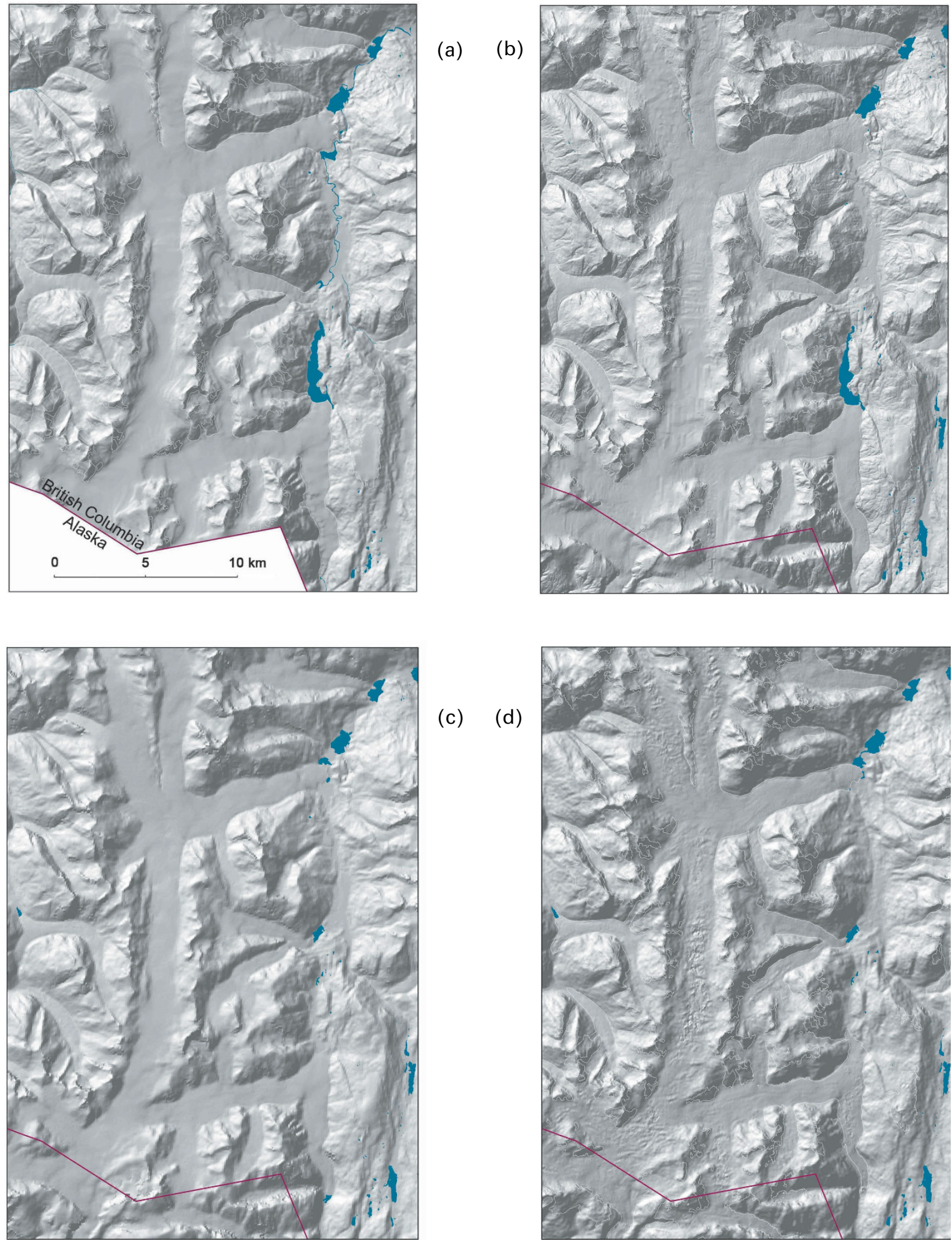

(c)

(d)

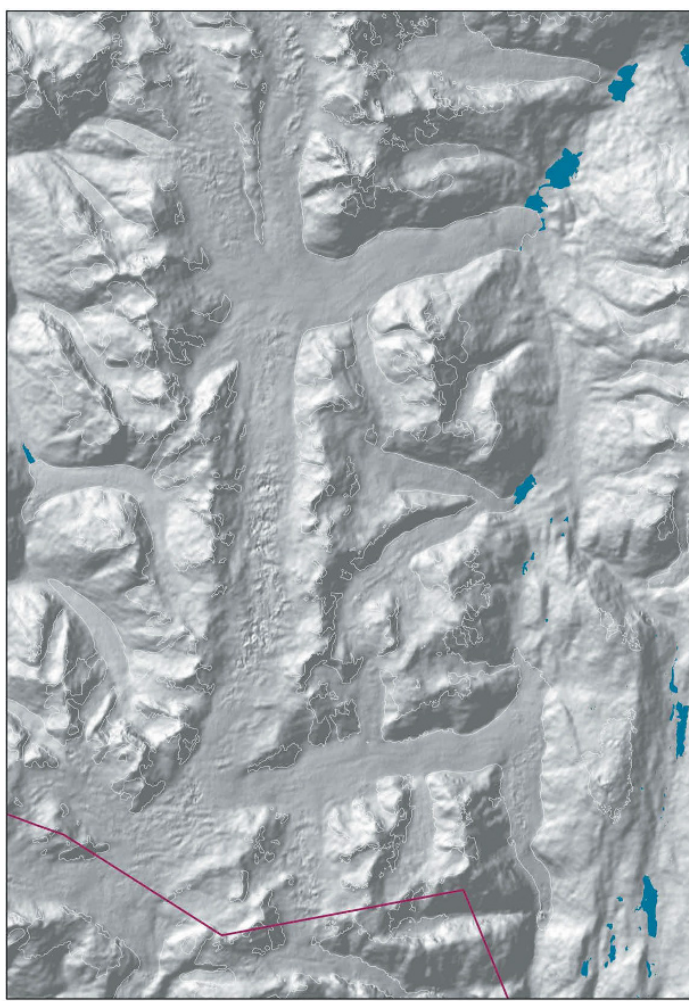

Figure 14.12. Hillshaded DEMs of the area including Salmon, Berendon, and Frank Mackie Glaciers in the northern Coast Mountains of British Columbia (56.2 N, 130 W): (a) 1965, (b) 1982, (c) 1999, (d) 2004. This DEM sequence can also be viewed as Online Supplement 14.4. 


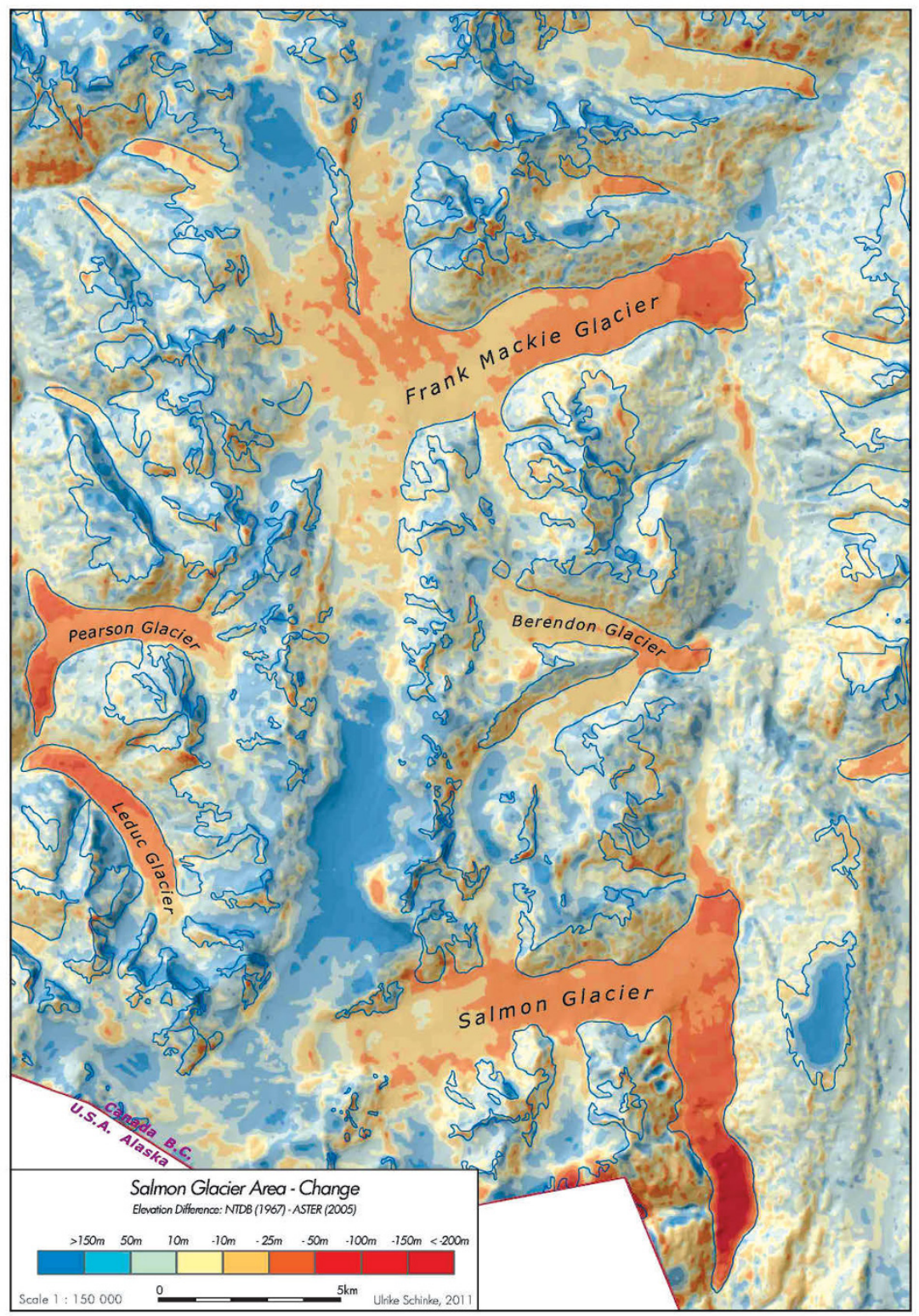

Figure 14.13. Ice surface elevation change from 1967 to 2005 of the area shown in Fig. 14.12. Figure can also be viewed as Online Supplement 14.5 .

Topographic Database (ftp:/|ftp2.cits.rncan.gc.cal pub/bndt/50k_shp_en/). Total ice-covered area in the Yukon in 1977 was $\sim 12,500 \mathrm{~km}^{2}$; most of this ice is in the St. Elias Mountains, which extend into Alaska and BC. Our inventory does not include glaciers in the McKenzie Mountains in eastern Yukon close to its border with Northwest Territory. Barrand and Sharp (2010) provide a complete glacier area inventory for the Yukon, including the McKenzie Mountains. They document a total reduction in glacier area of $22 \%$ between $1958-1960$ and 2006-2008.
Glacier elevation changes in the Yukon were determined by subtracting a map-derived DEM from a recent satellite-derived DEM. The earlier DEM was generated from the original (1977) map contour lines obtained from Geomatics Yukon (http://www.geomaticsyukon.ca/). Recent satellite DEMs have been generated from SPOT5-HRS stereo images acquired during the SPIRIT IPY project in 2007 and 2008 (Korona et al. 2009). They have an accuracy in glacierized areas of better than $\pm 10 \mathrm{~m}$ (Berthier and Toutin 2008). Unreliable elevations in the satellite DEMs were removed using 


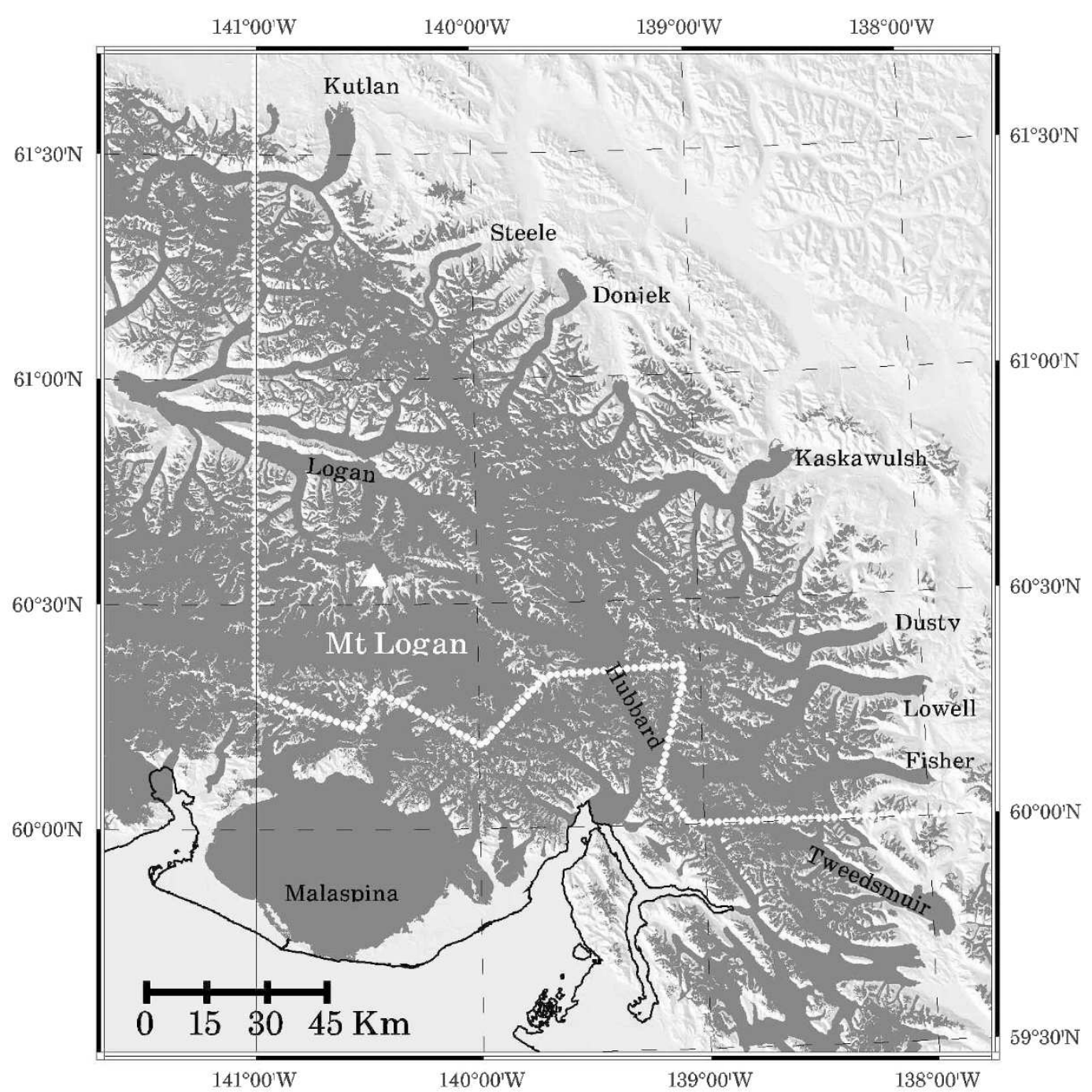

Figure 14.14. Shaded relief image of the GTOPO30 DEM showing the ice-covered area (darker gray) in Yukon Territory. The location of the summit of Mount Logan, the highest point in Canada $(5,959 \mathrm{~m}$ asl), is shown with a white triangle. The thick dotted line delineates the border between the Yukon and Alaska (to the west) and the Yukon and British Columbia (to the south).

the score channel provided with the SPIRIT product. SPOT5-HRS DEMs are automatically derived from stereo imagery without ground control points and thus may contain some planimetric and altimetric biases. These biases have been estimated and corrected using ICESat data acquired closest in time to the acquisition date of the satellitederived DEM. The map of ice elevation changes is shown in Fig. 14.15; elevation changes as a function of altitude are plotted in Fig. 14.16.

The mean ice loss for Yukon glaciers between 1977 and 2007 is $5.5 \pm 1.7 \mathrm{~km}^{3} / \mathrm{yr}$ (w.e.). The average mass balance for all glaciers in the Yukon over this period was $-0.45 \mathrm{~m} / \mathrm{yr}$ (w.e.). The greatest thinning, up to $120 \mathrm{~m}$, occurred at lower elevations (below 1,200 m asl). Above 1,200 m asl, thinning decreased to about 10-15 m. Most glacier ice in the Yukon lies between 1,000 and 3,000 m asl (Fig. 14.13).

The pattern of glacier elevation changes in the Yukon (Fig. 14.15) is not as complex as that in Alaska, where there are many surging and tidewater glaciers. Nevertheless, the elevation changes are far from homogeneous. Most low-elevation glacier tongues are shrinking; the exception is Dusty Glacier (Figs. 14.7 and 14.8). The upper reaches of some large glaciers, such as Tweedsmuir and Steele Glaciers, are thickening. It is thus not surpris- 


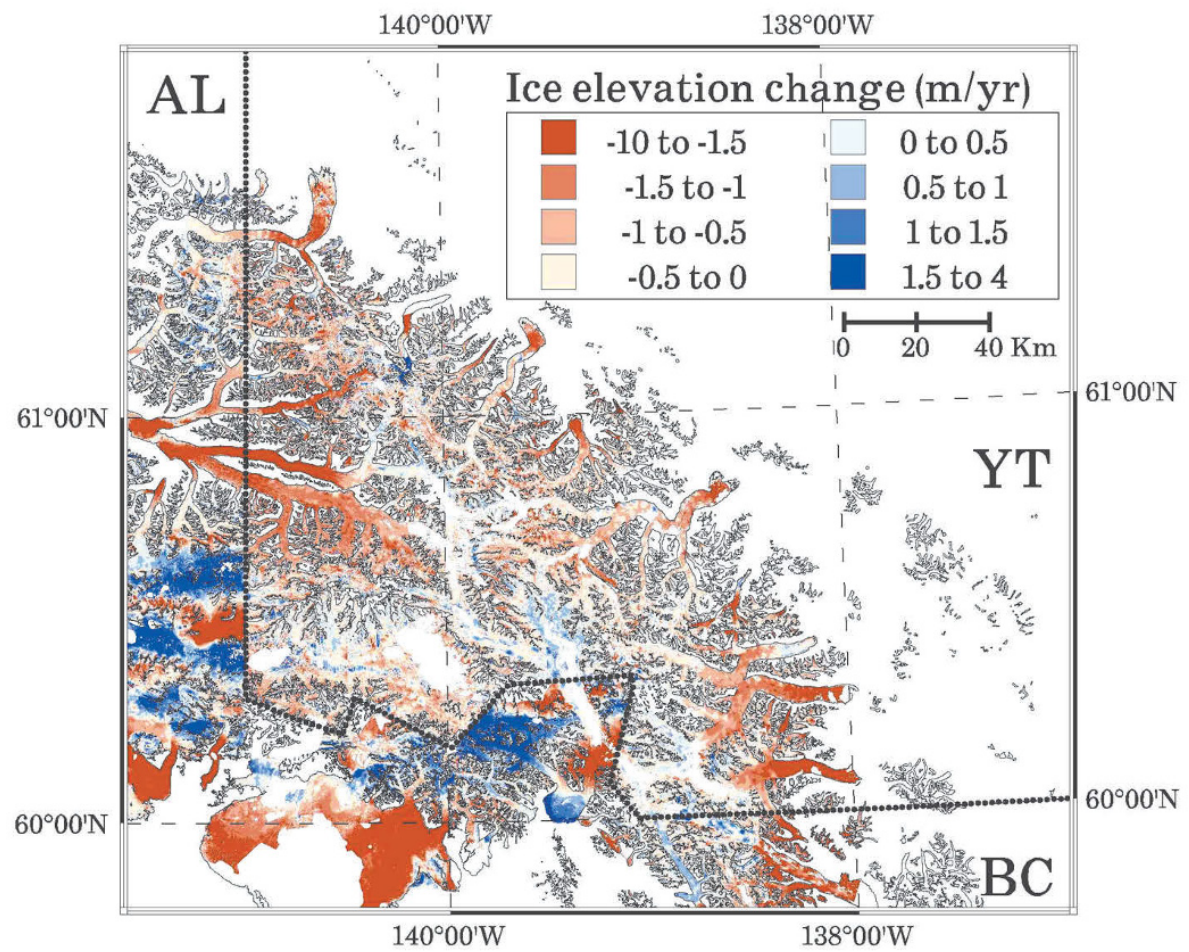

Figure 14.15. Glacier surface elevation changes (rates in $\mathrm{m} / \mathrm{yr}$ ) in the Yukon and adjacent areas of Alaska and British Columbia between 1977 and 2007. Regions where no reliable elevation change could be derived are white. Figure can also be viewed as Online Supplement 14.6.

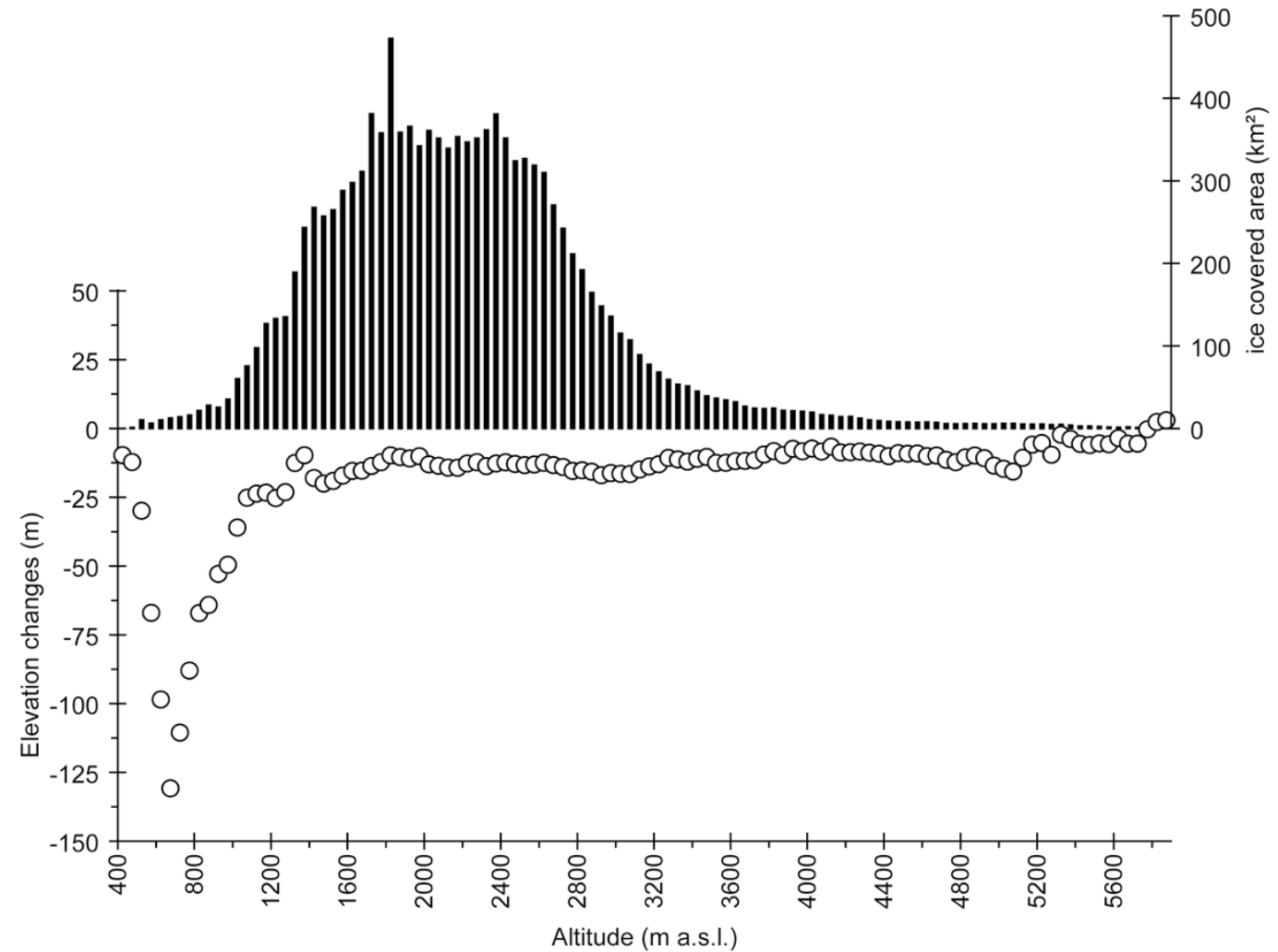

Figure 14.16. Glacier hypsometry (upper panel) and rate of ice surface elevation change versus altitude (lower panel) in the Yukon between 1977 and 2007. 
ing that Tweedsmuir Glacier started to surge in October 2007, after mass buildup in its accumulation area over the previous 30 years (http:// ak.water. usgs.gov/Projects/Tweedsmuir/; and Chris Larsen, pers. commun., 2009).

We are unable to check our satellite-derived mass balance estimates against field data, due to the general lack of field mass balance programs in the Yukon. Satellite-derived mass balances and field mass balance estimates for two glaciers in Alaska (Gulkana, Wolverine) surveyed by the U.S. Geological Survey, however, are in good agreement (Berthier et al. 2010). The only other estimate of ice elevation changes in the region was made by researchers at the University of Alaska Fairbanks, who differenced ice surface elevations obtained from recent airborne profiles with elevation contour lines extracted from the same (1977) map series as above (Arendt et al. 2009). They calculated a mass balance of about $-0.5 \mathrm{~m} / \mathrm{yr}$ for Kaskawulsh Glacier over the period 1977-2000, which is consistent with, although not independent of, our DEM-derived mass balance estimate.

\subsection{CONCLUDING REMARKS}

These studies illustrate the potential uses of repeat satellite imagery and multitemporal DEMs to monitor recent and ongoing changes in glaciers in western Canada. Spaceborne glacier monitoring also provides insights into other elements of the environment, such as water resources, vegetation change, and geohazards. In areas where summer precipitation is limited, such as the interior of BC and the eastern slopes of the Rocky Mountains, glacier thinning and retreat have reduced water supply to rivers in mid to late summer. Summer streamflow is augmented by glacier melt, providing benefits to urban, industrial, and agricultural users; it also moderates stream temperatures for aquatic organisms (Moore et al. 2009, Marshall et al. 2011). Continuous monitoring is needed to detect any acceleration in the rate at which these glaciers lose area and mass, and only imagery provided by satellite sensors such as Landsat, ASTER, and SPOT-5 can provide the spatial coverage required to detect and monitor glacier changes on a regional scale.

\subsection{ACKNOWLEDGMENTS}

Research examining glacier changes in British Columbia and Alberta was completed by the
Western Canadian Cryospheric Network $\left(\mathrm{WC}^{2} \mathrm{~N}\right)$. Work in the Yukon was funded by the Polar Climate Stability Network. Both networks were funded by the Canadian Foundation for Climate and Atmospheric Sciences (CFCAS). We also thank the Natural Sciences and Engineering Research Council of Canada (NSERC). ASTER data courtesy of NASA/ GSFC/METI/Japan Space Systems, the U.S./Japan ASTER Science Team, and the GLIMS project.

\subsection{REFERENCES}

Allen, S.M., and Smith, D.J. (2007) Late Holocene glacial activity of Bridge Glacier, British Columbia Coast Mountains. Canadian Journal of Earth Sciences, 44, 1753-1773.

Arendt, A.A., Echelmeyer, K.A., Harrison, W.D., Lingle, C.S., and Valentine, V.B. (2002) Rapid wastage of Alaska glaciers and their contribution to rising sea level. Science, 297, 382-386.

Arendt, A.A., Walsh, J., and Harrison, W. (2009) Changes of glaciers and climate in northwestern North America during the late 20th Century. Journal of Climate, 22, 4117-4134.

Barrand, N.E., and Sharp, M.J. (2010) Sustained rapid shrinkage of Yukon glaciers since the 1957-1958 International Geophysical Year. Geophysical Research Letters, 37, L07501.

Barry, R.G. (2008) Mountain Weather and Climate (Third Edition), Cambridge University Press, Cambridge, U.K.

Berthier, E., and Toutin, T. (2008) SPOT5-HRS digital elevation models and the monitoring of glacier elevation changes in northwest Canada and southeast Alaska. Remote Sensing of Environment, 112, 24432454.

Berthier, E., Schiefer, E., Clarke, G.K.C., Menounos, B., and Remy, F. (2010) Contribution of Alaskan glaciers to sea level rise derived from satellite imagery. Nature Geoscience, 3, 92-95.

Bolch, T., Menounos, B., and Wheate, R. (2010) Landsatbased inventory of glaciers in western Canada, 19852005. Remote Sensing of Environment, 114, 127-137.

Clarke, G.K.C. (2005) Subglacial processes. Annual Review of Earth and Planetary Sciences, 33, 247-276.

Clarke, G.K.C., and Holdsworth, G. (2002a) Glaciers of the Coast Mountains. In: R.S. Williams Jr. and J.G. Ferrigno (Eds.), Satellite Image Atlas of Glaciers of the World: North America (USGS Professional Paper 1386-J-1), U.S. Geological Survey, Reston, VA, pp. J291-J300.

Clarke, G.K.C., and Holdsworth, G. (2002b) Glaciers of the St. Elias Mountains. In: R.S. Williams Jr. and J.G. Ferrigno (Eds.), Satellite Image Atlas of Glaciers of the World: North America (USGS Professional 
Paper 1386-J-1), U.S. Geological Survey, Reston, VA, pp. J301-J311.

DeBeer, C., and Sharp, M. (2007) Recent changes in glacier area and volume within the southern Canadian Cordillera. Annals of Glaciology, 46, 215-221.

DeBeer, C., and Sharp, M. (2009) Topographic influences on recent changes of very small glaciers in the Monashee Mountains, British Columbia, Canada. Journal of Glaciology, 55(192), 691-700.

De Paoli, L., and Flowers, G.E. (2009) Dynamics of a small surge-type glacier investigated using onedimensional geophysical inversion. Journal of Glaciology, 55, 1101-1112.

Geertsema, M., and Clague, J.J. (2005) Jökulhlaups at Tulsequah Glacier, northwestern British Columbia, Canada. The Holocene, 15, 310-316.

Gratton, D., Howarth, P., and Marceau, D. (1990) Combining DEM parameters with Landsat MSS and TM imagery in a GIS for mountain glacier characterization. IEEE Transactions on Geoscience and Remote Sensing, 28, 766-769.

Kargel, J.S., Abrams, M.J., Bishop, M.P., Bush, A., Hamilton, G., Jiskoot, H., Kääb, A., Kieffer, H.H., Lee, E.M., Paul, F. et al. (2005) Multispectral imaging contributions to Global Land Ice Measurements from Space. Remote Sensing of Environment, 99, 187-219.

Kershaw, J.A., Clague, J.J., and Evans, S.G. (2005) Geomorphic and sedimentological signature of a twophase outburst flood from moraine-dammed Queen Bess Lake, British Columbia, Canada. Earth Surface Processes and Landforms, 30, 1-25.

Korona, J., Berthier, E., Bernard, M., Remy, F., and Thouvenot, E. (2009) SPIRIT. SPOT 5 stereoscopic survey of polar ice: Reference images and topographies during the fourth International Polar Year (20072009). ISPRS Journal of Photogrammetry and Remote Sensing, 64, 204-212.

Luckman, B., Harding, K., and Hamilton, P. (1987) Recent glacier advances in the Premier Range, British Columbia. Canadian Journal of Earth Sciences, 24, 1149-1161.

Marshall, S.J., White, E.C., Demuth, M.N., Bolch, T., Wheate, R., Menounos, B., Beedle, M.J., and Shea, J.M. (2011) Glacier water resources on the eastern slopes of the Canadian Rocky Mountains. Canadian Water Resources Journal, 36(2), 109-134, doi: 10.4296/ cwrj3602823.

Mathews, W.H., and Clague, J.J. (1993) The record of jökulhlaups from Summit Lake, northwestern British Columbia. Canadian Journal of Earth Sciences, 30, 499-508.

Moore, G.W.K., Holdsworth, G., and Alverson, K. (2002) Climate change in the North Pacific region over the past three centuries. Nature, 420, 401-403.
Moore, R., Fleming, S., Menounos, B., Wheate, R., Fountain, A., Holm, C., and Jakob, M. (2009) Glacier change in western North America: Influences on hydrology, geomorphic hazards, and water quality. Hydrologic Processes, 23, 42-61.

Ommanney, C.S.L. (1980) The inventory of Canadian glaciers: Procedures, techniques, progress and applications. Proceedings of the Riederalp Workshop, September 1978 (IAHS-AISH Publication No. 126), International Association of Hydrological Sciences, Rennes, France.

Ommanney, C.S.L. (2002a) Mapping Canada's glaciers. In: R.S. Williams Jr. and J.G. Ferrigno (Eds.), Satellite Image Atlas of Glaciers of the World: North America (USGS Professional Paper 1386-J-1), U.S. Geological Survey, Reston, VA, pp. J83-J110.

Ommanney, C.S.L. (2002b) Glaciers of the Canadian Rockies. In: R.S. Williams Jr. and J.G. Ferrigno (Eds.), Satellite Image Atlas of Glaciers of the World: North America (USGS Professional Paper 1386-J-1), U.S. Geological Survey, Reston, VA, pp. J199-J290.

Østrem, G. (1973) The transient snowline and glacier mass balance in southern British Columbia and Alberta, Canada. Geografiska Annaler, 55A, 120-128.

Østrem, G. (2006) History of scientific studies at Peyto Glacier. In: M.N. Demuth, D.S. Munro, and G.J. Young (Eds.), Peyto Glacier: One Century of Science (NHRI Science Report No. 8), National Hydrology Research Institute, Saskatoon, Saskatchewan, Canada, pp. 1-24.

Schiefer, E., Menounos, B., and Wheate, R. (2007) Recent volume loss of British Columbia glaciers, Canada. Geophysical Research Letters, 34, L16503, doi: 10.1029/2007GL030780.

Schiefer, E., Menounos, B., and Wheate, R. (2008) A comprehensive inventory of glaciers and glacier morphometry, British Columbia, Canada. Journal of Glaciology, 54, 551-560.

Shea, J.M., Marshall, S.J., and Livingston, J.M. (2004) Glacier distributions and climate in the Canadian Rockies. Arctic, Antarctic, and Alpine Research, 36(2), 272-278.

Sidjak, R., and Wheate, R. (1999) Glacier mapping of the Illecillewaet Icefield, British Columbia, Canada, using Landsat TM and digital elevation data. International Journal of Remote Sensing, 20, 273-284.

Stahl, K., Moore, R., Shea, J., Hutchinson, D., and Cannon, A. (2008) Coupled modelling of glacier and streamflow response to future climate scenarios. Water Resources Research, 44, W02422. doi: 10.1029/2007 WR005956.

VanLooy, J., and Forster, R. (2008) Glacial changes of five southwest British Columbia icefields, Canada, mid-1980s to 1999. Journal of Glaciology, 54, 469-478. 